\title{
A GIS-BASED VOLCANIC HAZARD AND RISK ASSESSMENT OF ERUPTIONS SOURCED WITHIN VALLES CALDERA, NEW MEXICO
}

\author{
Rebecca Alcorn
}

\begin{abstract}
A Thesis
Submitted to the Graduate College of Bowling Green

State University in partial fulfillment of the requirements for the degree of
\end{abstract}

\section{MASTER OF SCIENCE}

May 2013

Committee:

Kurt Panter, co-Advisor

Peter Gorsevski, co-Advisor

Xinyue Ye 


\section{ABSTRACT}

Kurt Panter, Co-Advisor

Peter Gorsevski, Co-Advisor

Valles caldera, in north-central New Mexico, is considered one of the largest rhyolitic volcanoes in the United States due to the great amount of volcanic activity over the last 1.61 Ma. Although Valles caldera is currently dormant, there is potential for future volcanic activity, and therefore it is prudent to assess the risk to the surrounding area well before a disaster strikes. The primary objective of this study is to develop one of the first volcanic risk assessments of the Valles caldera region through the evaluation of the spatial extent of different volcanic hazards and the assessment of social and economic vulnerability of the area at risk.

In this study, hazard maps are generated with a GIS-based volcanic hazards tool designed to simulate ash fallout, pyroclastic density currents (PDCs), and lava flows based on the Late Quaternary ( $\sim 55 \mathrm{ka})$ eruptions from within Valles caldera. Simulated ash fall deposits originating from El Cajete crater are calibrated to isopach and lithic isopleth maps of the Lower and Upper El Cajete ash fall deposits as constructed by Wolff et al. (2011) with modern environmental conditions. Additionally, the calibration of PDCs is conducted based on the distribution and runout of the Battleship Rock Ignimbrite. Once calibrated, hazards are simulated at two other vent locations determined from probability distributions of structural features, in order to generate the final hazard maps.

In assessing communities' hazard preparedness, social vulnerability is evaluated for all census-designated places within the study site through a principal component analysis of twentyfour variables shown to increase or decrease social vulnerability. Also, to assess the expected loss from hazards, economic vulnerability is evaluated through a multi-criteria evaluation (MCE) of population, land use, infrastructure, and economic production, where each factor is 
categorized and assigned a value representing relative vulnerability based on cost and importance.

Ultimately, the hazard maps and vulnerability assessments are aggregated through weighted linear combination and pairwise comparison matrices, creating a total of five risk maps. Although the actual maps provide greater detail, overall, the risk maps show that ash fall has the greatest impact, effecting areas up to $50 \mathrm{~km} \mathrm{~S} / \mathrm{SE}$ of the caldera, including highly vulnerable cities, such as Los Alamos, White Rock, and Santa Fe. The PDCs and lava flow hazards, however, impact significantly smaller areas, primarily disturbing low vulnerability forest. The methodology presented in this paper allows for a robust analysis of the risk the Valles caldera area is faced with in the event of volcanic hazards, which is especially useful in focusing mitigation strategies to reduce the loss from such hazard events. 
I dedicate my thesis to my loving parents, sister and brother for their unending support and encouragement, and for instilling the stubbornness in me to never give up. Without them I would have never made it this far. 


\section{ACKNOWLEDGEMENTS}

Above all, I would like to thank my advisors, Dr. Kurt Panter and Dr. Peter Gorsevski, for their patience, advice, and support in my research. I am extremely grateful for their willingness to explore a different realm of research and for strengthening my understanding and interest of natural hazards and risk management. I thank Dr. Kurt Panter particularly for his expertise in volcanic processes and encouraging me to undertake this research project; and I thank Dr. Peter Gorsevski especially for his assistance in helping me to understand unfamiliar decision-making modeling tools and introducing me to a world of new technology.

I would also like to thank my committee member, Dr. Xinyue Ye for his commitment to my research and his expertise as a social geographer. Moreover, I would like to express my gratitude to Dr. Christopher Emrich at the Hazards and Vulnerability Research Institute for his guidance and assistance in generating the social vulnerability index. I am also very grateful to William Butcher for his relentless IT support throughout my research.

Finally, I would like to thank my family and friends for their unending love and support, and for encouraging me and motivating me throughout this entire process, as well as my fellow graduate students, who shared the joys and difficulties of this research and education experience with me. 
TABLE OF CONTENTS

Page

1. INTRODUCTION …................................................................................... 1

2. GEOLOGIC BACKGROUND ....................................................................

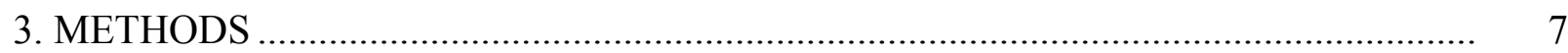

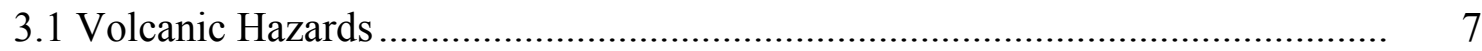

3.1.1 Vent Locations ............................................................................. 8

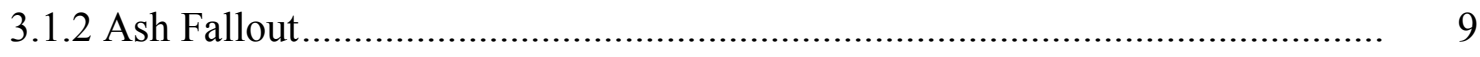

3.1.3 Pyroclastic Density Currents .......................................................... 12

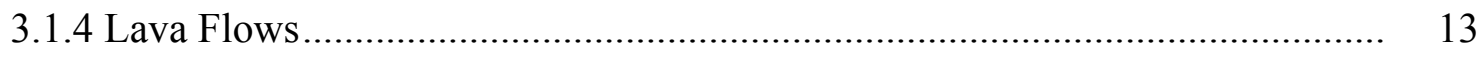

3.2 Social Vulnerability ......................................................................... 14

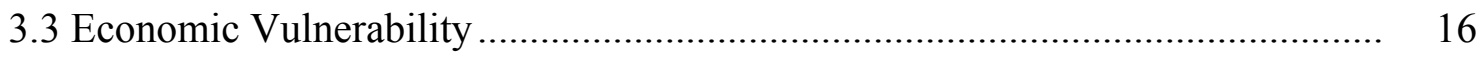

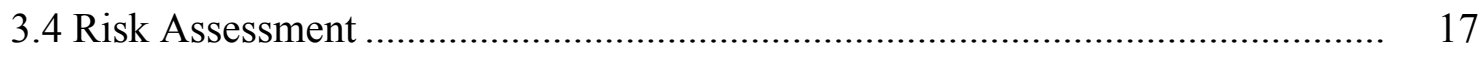

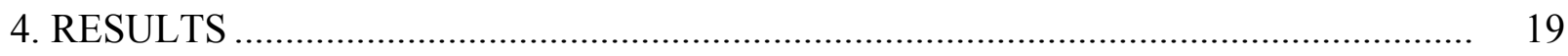

5. DISCUSSION ............................................................................................ 22

6. CONCLUSIONS............................................................................................ 26

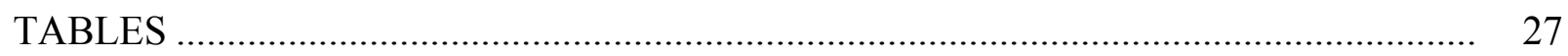

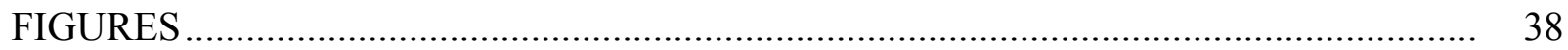

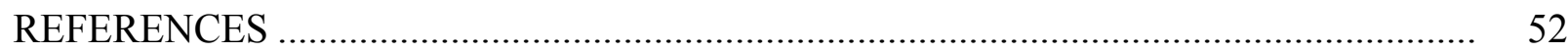

APPENDIX A. Probability Density Function Methods .......................................... 57

APPENDIX B. Ash Fallout Simulation Methods ................................................... 62

APPENDIX C. PDC Simulation Methods ................................................................ 64

APPENDIX D. Lava Flow Simulation Methods ......................................................... 65 
APPENDIX E. Principal Component Analysis ............................................................ 67

APPENDIX F. Data for Economic Vulnerability ..................................................... 71 


\section{LIST OF TABLES}

Table

Page

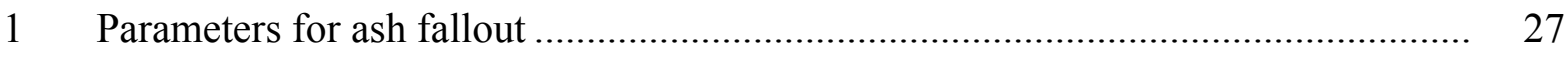

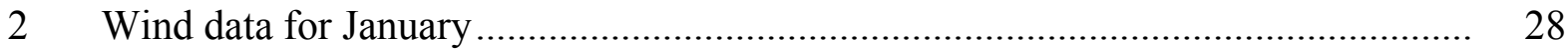

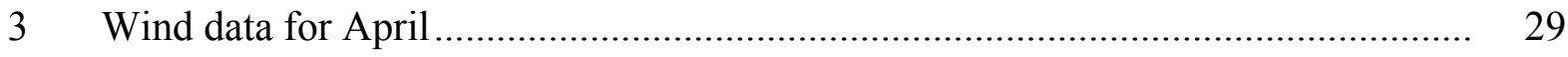

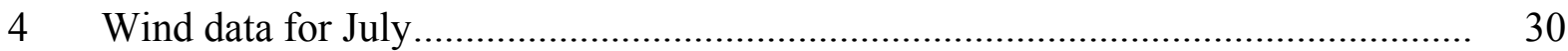

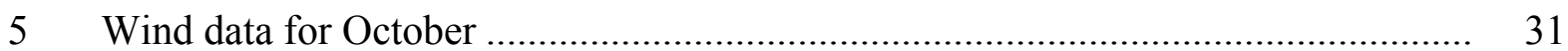

$6 \quad$ Parameters for calibrating pyroclastic density currents ...................................... 32

$7 \quad$ Variables for social vulnerability assessment ..................................................... 33

$8 \quad$ Variable loadings for components for social vulnerability index ............................. 34

$9 \quad$ Categorization of factors for economic vulnerability ...................................... 35

10 Pairwise comparison matrix for economic vulnerability ................................... 36

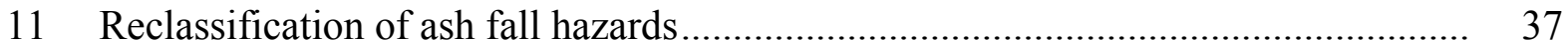

12 Pairwise comparison matrix for total risk ..................................................... 37 


\section{LIST OF FIGURES}

Figure

Page

1 DEM location map of the study area including the 55 census designated places focused on in the vulnerability assessments ................................................. 38

2 Conceptual framework for developing the overall risk assessment........................ 39

3 Vent susceptibility map generated from probability distribution of vents, faults, springs and fumaroles

$4 \quad$ Vent susceptibility map generated from probability distribution of vents and faults

5 Maps of the Lower El Cajete calibration for each month of wind data

6 Maps of the Upper El Cajete calibration for each month of wind data

7 Maps of the Battleship Rock Ignimbrite calibration for PDCs of different collapse equivalent heights and angles

8 Maps of the lava flow simulations at vents A and B.....

9 Individual maps of the standard deviation from the mean of principal component scores for each CDP

10 Map of the standard deviation from the mean of the total social vulnerability score for each CDP

11 Individual maps of the economic vulnerability for each factor 48

12 Map of total economic vulnerability for the entire study site....

13 Total risk maps for ash fallout hazards, varied by size of eruption and location ...... 50

14 Total risk map for PDC hazards sourced from vents A and B........................... 51 


\section{INTRODUCTION}

Jemez volcanic field in north-central New Mexico is best known for the two cataclysmic eruptions that formed Valles caldera at 1.61 and $1.25 \mathrm{Ma}$, which were followed by an extended period of relatively small-scale activity limited to within the caldera moat (Phillips et al., 2007). After a $\sim 46$ ka period of dormancy, new Plinian activity sourced from El Cajete crater in the southern region of the caldera began at $\sim 55 \mathrm{ka}$, dispersing tephra well beyond the caldera wall (Reneau et al., 1996; Goff and Gardner, 2004). This period of eruptive activity ended with the eruption of the Banco Bonito lava flow at $\sim 40 \mathrm{ka}$, and Valles caldera has lain dormant since (Goff and Gardner 2004; Gardner et al., 2010).

Although Valles caldera is currently dormant and an eruption is not imminent in the near future, a risk assessment is essential to have in place so that proper mitigation strategies may take place well before disaster strikes. With the exception of a report by Los Alamos National Lab (Keating et al., 2010), there has been virtually no hazard or risk assessment generated for communities in this region of New Mexico, making this an ideal area for conducting such an investigation. Thus, the overall purpose of this study is to implement a geographic information system (GIS)-based volcanic risk assessment of the area surrounding Valles caldera in northcentral New Mexico. Risk assessments involve the evaluation of the potential hazards that threaten an area as well as the vulnerability of elements (i.e. communities, infrastructure) exposed to such hazards (Bell, 1999; Blong, 1996; UNESCO). Consequently, the assessment for this study of the Valles caldera area involves three primary objectives: (1) evaluating the spatial extent of three types of volcanic hazards, (2) assessing communities' social vulnerability to hazards, and (3) evaluating the economic vulnerability of different elements in the area. The 
three objectives are then aggregated through a GIS-based multi-criteria evaluation (MCE) to assess the total risk.

MCE analysis is a robust decision-making technique that forms a single index of evaluation through the assessment of multiple objectives and criteria. The advantage to this approach is that there is a significant amount of flexibility in the choice of criteria and the method for combining the criteria. The integration of GIS and MCE provides a powerful tool for determining the spatial preferences of different decision-making tasks. For this reason, over the last twenty-five years or so, MCE analysis has become increasingly useful in the evaluation of natural hazards and risk (Malczewski, 2006). For instance, MCE methodology has been used to combine various hazards and/or vulnerability criteria in numerous studies including, but not limited to, flood risk assessments (Meyer, et al., 2009; Wang et al., 2011; Musungu, 2012), seismic hazard and assessments (Erden and Karaman, 2012; Martins et al., 2012), and other volcanic risk assessments (Aceves-Quesada et al., 2007). In this study, MCE analysis combines the three objectives, the hazards, social, and economic vulnerability, through a weighted linear combination (WLC) and pairwise comparison matrix, in which each objective is weighted through an analytical hierarchy process, which evaluates the importance of each objective in the assessment of volcanic risk, and aggregated into a final risk index score.

Prior to combining each of the objectives into a risk assessment, each objective is individually assessed. In evaluating different volcanic hazards for this study, ash fallout, pyroclastic density currents (PDCs) and lava flows are considered the most likely to affect the study area given the volcanic history of Valles caldera. The spatial extent of each type of hazard is assessed by hazard maps generated with a GIS model specialized in simulating these three types of volcanic hazards. Simulations are conducted using realistic parameters based on the 
most recent eruptive activity within Valles caldera, combined with modern environmental conditions. The hazard maps reveal ash fallout generated the most widespread hazard, depositing ash as far as $\sim 50 \mathrm{~km}$ south and southeast of Valles caldera. As anticipated, PDCs impact a significantly smaller area than ash fallout, contained to within $\sim 10 \mathrm{~km}$ of Valles caldera, and based on the maps, future lava flows would most likely not travel more than $2 \mathrm{~km}$ from their source.

To assess the vulnerability of the elements threatened by such hazards, the vulnerability component of the risk assessment is divided into social and economic vulnerability. The social vulnerability assessment is conducted to evaluate communities' relative levels of hazard preparedness, while the economic vulnerability assessment is performed to evaluate the expected loss from a volcanic hazard. Social vulnerability is generated through a principal component analysis of twenty-four variables predetermined to influence communities' ability to cope with hazards as defined by the Hazards and Vulnerability Research Institute (HVRI, 2012). Economic vulnerability is assessed through a MCE of four primary factors thought to produce the greatest loss in the event of a hazard, including population, land use, infrastructure, and economic units. 


\section{GEOLOGIC BACKROUND}

In order to understand the types of volcanic hazards an area may be exposed to, it is crucial to understand the volcanic history of the source area from which future eruptions may occur. For this study the Jemez volcanic field in north-central New Mexico is considered for future eruptions, specifically focusing on eruptions sourced within Valles caldera.

Jemez volcanic field lies at the intersection of the Rio Grande Rift, a region of crustal thinning, and the Jemez lineament, a traverse shear zone, in north-central New Mexico (Baldridge and Olsen, 1989; Steck et al., 1998; Self 1990; Goff, 2009). Due to its unique location, Jemez volcanic field has been the most productive source of Quaternary volcanism in New Mexico (Dunbar, 2005). This area is best known for the two caldera-forming eruptions of Valles caldera at 1.61 and 1.22 Ma, which produced the lower and upper Bandelier tuffs, respectively, and made Valles caldera one of the largest silicic volcanoes of the late Cenozoic, in the United States (Spell et al., 1996; Phillps et al., 2007). Following the cataclysmic eruptions of the Bandelier tuffs, a series of comparatively minor rhyolite domes and lava flows, known as the Valles Rhyolites, erupted along a ring fracture in the north of the caldera from 1.13 to $0.52 \mathrm{Ma}$ (Spell and Harrison, 1993; Phillips et al., 2007) giving Valles caldera its distinct geometry still visible today (Wolff et al., 2011). Following this series of eruptions, Valles caldera remained dormant for $\sim 46 \mathrm{ka}$ (Wolff et al., 2011).

The most recent eruptive activity in Valles caldera began at $\sim 55 \mathrm{ka}$ (Reneau et al., 1996; Goff and Gardner, 2004). This activity has been restructured in the stratigraphic sequence and is now known as the East Fork Member, the youngest member of the Valles Rhyolite (Gardner, 2010; Wolff et al., 2011). The East Fork Member deposits include the El Cajete Pyroclastic Beds, Battleship Rock Ignimbrite, and Banco Bonito Flow, all of which originated at or near El 
Cajete crater, a vent in the southern region of Valles caldera (Gardner, 2010; Wolff et al., 2011). The El Cajete Pyroclastic Beds are divided into the Lower and Upper El Cajete deposits consisting primarily of Plinian pumice fall dispersed to the southeast and southwest of the El Cajete crater, respectively (Wolff et al., 2011). Although only exposures near Valles caldera have been mapped, the Lower El Cajete eruption has been estimated to have deposited $\sim 50 \mathrm{~cm}$ of tephra as far away as Santa Fe, a major city $\sim 50 \mathrm{~km}$ southeast of the caldera (Wolff et al., 2011). The timing and dynamics of the eruption of Battleship Rock Ignimbrite has not been as well constrained as the El Cajete eruptions; however, the Upper El Cajete fall deposits are interspersed with PDC deposits, which may be considered equivalent to the lower two units of Battleship Rock Ignimbrite (Wolff et al., 2011). Assuming Battleship Rock Ignimbrite originated from the El Cajete vent as well, geologic maps show the ignimbrite deposit extended at least 8 $\mathrm{km}$ to the west of the crater, but did not breach the caldera wall (Self et al., 1988). Following the El Cajete and Battleship Rock eruptions, the Banco Bonito Flow erupted from a vent approximately $1 \mathrm{~km}$ northwest of El Cajete crater at $\sim 40 \mathrm{ka}$ (Self et al., 1998; Wolff et al., 2011). The Banco Bonito is an obsidian flow and is considered to have erupted over a period of several months and is thought to consist of multiple flow units extending up to $8.5 \mathrm{~km}$ west of the vent (Self et al., 1988; Wolff et al., 2011). Since the eruption of the Banco Bonito, Valles caldera has been dormant.

Although an eruption similar to the caldera-forming eruptions of the Bandelier tuffs would clearly pose the most devastating destruction to the study area, an eruption of this size is unlikely in the near future (Wolff et al., 2011). The East Fork Member is compositionally and petrographically distinct from any previous eruptions, indicating a new magma source and type of activity (Wolff and Gardner, 1995; Wolff et al., 2011). Therefore, it is expected that the most 
likely type of eruption to occur in the future would be one comparable to the eruptions that produced the East Fork Member units (Wolff et al., 2011). Based on the eruptions of the East Fork Member, the primary hazards chosen for investigation in this study include, ash fallout, PDCs, and lava flows represented by the El Cajete, Battleship Rock, and Banco Bonito deposits, respectively. Each deposit served as a prototype for estimating the distribution of these volcanic hazards. 


\section{METHODS}

The aim of this thesis was to test and demonstrate a MCE case study for assessing risk in the volcanic prone area of Valles caldera. The study site was selected to cover a $75 \mathrm{x} 80 \mathrm{~km}$ area surrounding Valles caldera, encompassing fifty-five communities within Rio Arriba, Sandoval, Santa Fe, and Los Alamos counties that could be impacted by future volcanic hazards (Figure 1). In performing the MCE analysis, three primary objectives including, the volcanic hazards, social vulnerability, and economic vulnerability, were considered and aggregated to calculate the total risk. Prior to performing the MCE analysis, however, each objective had to be assessed through the evaluation of a series defining factors by various methods (Figure 2). For example, the spatial extent of the volcanic hazards was assessed through GIS-model simulations of individual hazards, including, ash fall, pyroclastic density currents, and lava flows. On the other hand, the social vulnerability of each of the fifty-five communities within the study site was evaluated through a principal component analysis of eight statistically significant components. And finally, the economic vulnerability was assessed through its own MCE of four economically significant factors. After each objective was evaluated, the MCE analysis aggregated the three objectives into a final risk index through the use of a weighted linear combination and pairwise comparison matrix.

\subsection{Volcanic Hazards}

To assess the impact of volcanic hazards on the study area, hazard maps showing the distributions of the three primary types of volcanic hazards known to the area (ash fallout, PDCs, and lava flows) were generated through computer simulations. Simulations were conducted by VORIS 2.0.1, a GIS-based tool specialized for use in volcanic hazard assessment (Felpeto, 2009). Assuming, that a future eruption will most likely reflect the size and style of the East Fork 
Member eruptions, simulations were first conducted at El Cajete crater to calibrate the parameters for each hazard to the distribution of the El Cajete Pyroclastic Beds, Battleship Rock Ignimbrite, or Banco Bonito Flow under modern environmental conditions (i.e. wind speed and direction and topography). Once calibrated, rather than generating the final hazards maps at former vents, new vent locations were considered for the source of each of the hazards. The vent locations were predicted by modeled susceptibility of various geological features.

\subsubsection{Vent Locations}

In order to determine probable future vent locations from which to simulate each of the volcanic hazards, vent susceptibility maps showing the spatial probability for the opening of a future vent were generated (Felpeto, 2009; Marti and Felpeto, 2010). The vent susceptibility maps were primarily constructed from structural features thought to be influential in determining the location of volcanic vents. For this study, these features included existing vents, faults, fumaroles, and springs. Shapefiles of each of the structural features were extracted from the most recent geologic map of Valles caldera (Goff et al., 2011). From these, four corresponding probability density maps were then created through Gaussian or Cauchy kernel functions to evaluate each feature's spatial distribution throughout Valles caldera (Appendix A). To determine the overall vent susceptibility from these features, the probability density maps of each of the structural features were weighted based on their relevance to a vent location and summed, creating the final vent susceptibility map.

Two final vent susceptibility maps were generated through this process, where one of the maps used all four geologic factors, while the second map used only the vent and fault distributions. Because the vent and fault probability distributions covered most of the Valles Caldera area, the susceptibility map produced by all four variables relied mostly on the 
probability distribution of the fumaroles and springs. This map was still considered useful since fumaroles and springs may have some indication of possible future vent locations; however, a second vent susceptibility map was generated based solely on the vent and fault distribution to take into account other possible vent locations that may have been overlooked by the first map. The first map, referred to as susceptibility map A, produced a cluster of high probability vent locations in the western region of the caldera, while the second map, susceptibility map B, produced a distinctly different cluster of high probability vent locations on the southeastern caldera rim (Figures 3 and 4). In both cases, the weighting of the different geologic variables had minimal impact on the final output. Therefore, for susceptibility map A, each structural factor was assigned an equal weight of 0.25 and summed together, to calculate the total susceptibility for every $30 \mathrm{~m}$ pixel in the study area. Similarly, for susceptibility map B, both structural factors were assigned a weight of 0.5 and summed.

Since both maps A and B produced different clusters of high probability locations, one vent was selected from each map from which to run the hazard simulations, considered vent A and vent B, respectively. Each of the vents were chosen from a relatively central point with the highest probability from within each cluster.

\subsubsection{Ash Fallout}

Simulations for ash fallout were conducted through an advection-diffusion model designed for Plinian-style eruptions. The basis for the model lay in the assumption that far from the vent particle motion is controlled by advection from wind, diffusion of particles, and particle's terminal settling velocity (Appendix B; Pfeiffer et al., 2005; Felpeto, 2009). In order to simulate ash fallout comparable to deposits from the East Fork Member eruptions, model constraints dependent on the size and style of the eruption were estimated based on field 
observations of the Lower and Upper El Cajete pyroclastic fall deposits. Values for these parameters were calibrated by comparing model simulations originating at El Cajete crater under modern environmental conditions with isopach and isopleth maps from Wolff et al. (2011).

In the model, eruption volume, column height, particle size, and a coefficient known as the A-parameter were required in order to determine the initial distribution of particles vertically over the vent. Parameter values for volume, column height and particle size were chosen directly from field observations and estimates as described by Wolff et al. (2011) (Table 1). The Aparameter, however, was experimentally determined through trial simulations. Pfeiffer et al. (2005) introduced the A-parameter as a coefficient used to describe the mass concentration of particles relative to the column height. Based on observations, it has been estimated that an Aparameter of 4 generates the most ideal column shape with the maximum mass concentration at the height of neutral buoyancy (Pfeiffer et al., 2005). However, with limited knowledge of the El Cajete eruption column dynamics and to ensure an A-parameter most reflective of the El Cajete eruptions, different coefficients were tested by fitting the resulting ash distributions from simulations with isopach maps generated by Wolff et al. (2011). In the end, the A-parameter had minimal impact on the isopach shape and area for both the Lower and Upper El Cajete eruptions, so the recommended A-parameter of 4 was accepted.

In order to model the transport of the particles dispersed within the column, constraints for particle diffusion, advection of wind, and terminal settling velocity were also used. The horizontal diffusion of particles depended on a large variety of factors such as the scale of the eruption and particle dimensions, making it difficult to constrain (Folch and Felpeto, 2005; Pfeiffer et al., 2005; Macedonio et al., 1988). As a result, the horizontal diffusion coefficient was best estimated by fitting simulated isopach maps to field observations, similarly to the calibration 
of the A-parameter (Pfeiffer et al., 2005; Macedonio et al., 1988). Ash distribution patterns were simulated from horizontal diffusion coefficients ranging from $200 \mathrm{~m}^{2} / \mathrm{s}$ to $10,000 \mathrm{~m}^{2} / \mathrm{s}$ (Pieffer et al., 2005; Macedonio et al., 1988). Comparing the different ash distributions to the isopach maps from Wolff et al. (2011), a horizontal diffusion coefficient of $3,000 \mathrm{~m}^{2} / \mathrm{s}$ was determined to produce an output best fitted to both the Lower and Upper El Cajete isopach maps (Wolff et al., 2011).

Data for modeling the advection of particles from wind was compiled from the University of Wyoming Department of Atmospheric Science sounding database. Daily records from Albuquerque, the nearest station to Valles caldera that lies $\sim 80 \mathrm{~km}$ to the south, were used to calculate monthly average wind height, speed, and direction at $1000 \mathrm{~m}$ altitude intervals up to $\sim 32$ to $34 \mathrm{~km}$ for January, April, July, and October 2012 (Tables 2 - 5). One month from each season was chosen to account for potential seasonal variations in wind direction and intensity, which would in turn cause variations in ash fall dispersal patterns. Since January and July wind conditions best produced axial orientations and dispersal patterns most reflective of the Lower and Upper El Cajete eruptions, respectively, the wind data for these months were used in the calibration of the former parameters. However, wind conditions for all four seasons were evaluated in simulations for the actual hazard maps.

The terminal settling velocity of different particles was dependent on parameters including, the viscosity and density of air, particle density, and drag. Depending on the height of the particles, the model assumed different atmospheric conditions to calculate viscosity and density of air; standard atmospheric conditions were used for particles below tropopause, while isothermal conditions were used above the tropopause (Folch and Felpeto, 2005). To determine the boundary between standard and isothermal conditions, the height of the tropopause was 
estimated at approximately $12,500 \mathrm{~m}$ based on the drastic change in wind speeds occurring at that altitude in all four months of wind data. Particle densities estimated by Folch and Felpeto (2005) of $2380 \mathrm{~kg} / \mathrm{m}^{3}, 1200 \mathrm{~kg} / \mathrm{m}^{3}$, and $800 \mathrm{~kg} / \mathrm{m}^{3}$ were considered reasonable values for use in calculating terminal settling velocities of ash, coarse ash and lapilli, respectively. Additionally, due to limitations in constraining the drag coefficient, the VORIS default drag coefficient of 3.45 experimentally determined by Folch and Felpeto (2005) was also accepted as sufficient.

After calibrating parameters under modern environmental conditions to produce Lower and Upper El Cajete-type ash distributions (Figures 5 and 6), simulations were conducted at vents A and B for the months of January, April, July and October, to determine areas that may potentially be affected by future eruptions.

\subsubsection{Pyroclastic Density Currents}

Pyroclastic density currents (PDCs) were simulated with an energy cone model, constrained by the topography, collapse equivalent height of the column, and a friction parameter, known as the collapse equivalent angle (Appendix C; Felpeto, 2009). A $30 \mathrm{~m}$ digital elevation model was used as the topography during the PDC simulations. The DEM was derived through the compilation of the United States Geological Survey (USGS) 10 m quadrangle DEMs provided by the New Mexico Resource Geographic Information Systems and resampled to $30 \mathrm{~m}$ due to the resolution of other criteria later on in the MCE (NMRGIS, 2012). The eruptive constraints of the PDC simulation were estimated from the extent of Battleship Rock Ignimbrite, the best example of a PDC from the East Fork Member.

To begin, the collapse equivalent angle, $\theta$, was calculated by:

$$
\theta=\arctan \left(\frac{H_{c}}{L}\right)
$$


where $H_{c}$ is the collapse equivalent height and $L$ is the runout length (Felpeto, 2009). For all simulations, the runout length was considered equivalent to the most distal exposure of Battleship Rock Ignimbrite $8 \mathrm{~km}$ from El Cajete crater (Self et al., 1988). Unfortunately, there was limited information on the dynamics of the eruption that produced Battleship Rock Ignimbrite and the factors most influential in determining the collapse equivalent height. Consequently, to simulate PDCs most similar to the Battleship Rock Ignimbrite different collapse heights ranging from 100 to $1500 \mathrm{~m}$ above the vent, the suggested range from model developers, were tested with corresponding friction parameters (Table 6; Malin and Sheridan, 1982; Felpeto, 2009). The suggested range was confirmed reasonable with studies by Clarke et al. (2002) and Sparks and Wilson (1978), who estimated the heights of the jet propulsion region of eruption columns from modeled and observed PDCs. Clarke et al. (2000) estimate a range of collapse heights from $\sim 800 \mathrm{~m}$ to $\sim 1500 \mathrm{~m}$ above the vent, and Sparks and Wilson (1978) estimated a range $600 \mathrm{~m}$ to $900 \mathrm{~m}$, similar to the range of tested values in this study. Using El Cajete crater as the source vent, simulations were fit with geologic maps of the Battleship Rock Ignimbrite. Based on the calibration, a collapse equivalent height of $1500 \mathrm{~m}$ and angle of $10.6^{\circ}$ were determined to produce a PDC most similar to the known distribution of the Battleship Rock Ignimbrite (Figure 7). Although the topography of the area has significantly changed since the eruption of the Battleship Rock Ignimbrite, the area and extent of the simulated PDC were still similar to the Battleship Rock Ignimbrite. With these constraints, PDC simulations were then conducted at vents $\mathrm{A}$ and $\mathrm{B}$.

\subsubsection{Lava Flows}

The lava flow simulations relied on a topography-driven probabilistic model to determine the paths of a hypothetical lava flow (Appendix D; Felpeto 2007; Felpeto, 2009). In the model, 
the dynamics of the lava flow were constrained by parameters for maximum flow length and flow height, or thickness. To simulate the lava flows the maximum flow length and thickness were estimated from the Banco Bonito Flow, the only exposed lava deposit of the East Fork Member of the Valles Rhyolite. Maximum flow length was estimated from the farthest known extent of Banco Bonito, 7 to $8.5 \mathrm{~km}$ from its source (Self et al., 1988; Bailey et al., 1969). The thickness of Banco Bonito was more difficult to constrain since it is more variable throughout the region. The maximum thickness measured, approximately $149 \mathrm{~m}$, was estimated from a drillcore (VC-1); however, it has been thought the flow is of unusual thickness in this area due to a paleovalley, making the flow four times thicker than its nearest surface exposures (Goff, 1986). This estimation was the best constraint for the thickness of the Banco Bonito; therefore, a height correction of $37.25 \mathrm{~m}$ was applied in the simulations. Topography for the lava flow simulations was derived from the $30 \mathrm{~m}$ DEM used for the PDC simulations. Since the lava flow simulation was driven purely by topography and there has been significant change to the topography since the eruption of the Banco Bonito Flow, it was not possible to calibrate the flow at El Cajete Crater; therefore, simulations were only conducted to estimate future hazards at vents A and B (Figure 8).

\subsection{Social Vulnerability}

In this study, social vulnerability was a measure of a person's ability to respond to and recover from a natural hazard, which is crucial to understanding the risk associated with different communities (HVRI, 2012). Cutter et al. (2003) originally developed a frequently referenced methodology for assessing social vulnerability, the Social Vulnerability Index (SoVI), which has since been modified and improved by the Hazards and Vulnerability Research Institute (HVRI) over the past decade. Currently, HVRI (2012) recognizes thirty socioeconomic variables 
representative of social and place inequalities, which have been studied to increase or decrease a community's social vulnerability. With these variables and the SoVI, the HVRI (2012) has calculated the social vulnerability of every county in the United States through a principal component analysis (PCA). For this study, the methodology developed by Cutter et al. (2003) and HVRI (2012) for performing the SoVI was modified to account for the variability in social vulnerability strictly within the study site. To show the maximum variability, the SoVI was conducted on a smaller scale, focusing on census-designated places (CDPs). Within the study site, the CDPs included a total of fifty-five cities and towns where populations were primarily focused. This scale allowed for an easy visualization of the variation in social vulnerability of individual communities within the study site, rather than entire counties.

From the thirty variables compiled by HVRI (2012), twenty-four variables were chosen as proxies for social vulnerability for this study due to the availability of data from the American Community Survey on the CDP-level (Table 7). According to Hatcher (1994), in order to ensure an adequate sample size for the PCA there should be at least five times the number of subjects as variables. Therefore, in conducting the PCA, data for each of the twenty-four variables was downloaded from an expanded area encompassing 228 CDPs in the twelve counties within and surrounding the study site. Based on the methods described by Cutter et al. (2003), Schmidtlein et al. (2008) and HVRI (2012), the variables were then standardized to z-scores and with the use of PCA, reduced to eight statistically significant components by extracting all components with an eigenvalue greater than one. The eight principal components in this study, included: ethnicity, age, class, poverty/unemployment, wealth, wealth/extractive employment, gender and race (Appendix E). Together, the eight components accounted for $64 \%$ of the total variance in the data (Table 8). The component scores for each CDP were then extracted, assigned appropriate 
cardinality, and summed to calculate the total vulnerability score (Appendix E; Figure 9).

Although for analysis the sample area was expanded to 228 CDPs, to compare the vulnerability of the fifty-five CDPs of concern, the standard deviation of each vulnerability score from the mean of the fifty-five CDPs was used to map the social vulnerability of the study site (Figure 10). Standard deviations were divided into three categories, including: high vulnerability $(>+0.5$ standard deviations), moderate vulnerability $(-0.5$ to 0.5$)$, and low vulnerability $(<-0.5)$.

\subsection{Economic Vulnerability}

In this study economic vulnerability was considered a measure of the direct impact of a hazard on the elements in the area at risk, or a measure of the economic cost (Aceves-Quesada et al., 2007). Economic vulnerability was assessed based on the methods of Aceves-Quesada et al. (2007) by means of a MCE of four primary factors, including: population, infrastructure (housing units, road type, schools and hospitals), land use, and economic production. Population, housing units, and number of schools and medical facilities, were mapped per CDP, and economic production was mapped per economic unit, which coincided with six of the CDPs. Road type and land use, on the other hand, were mapped over the entire study site (Appendix F).

To begin, the factors were converted to a common scale by categorizing each factor into four classes ranging from low to high vulnerability and assigning a corresponding value from 0 to 1 based on the relative significance of loss (Table 9; Figure 11). Once the factors were scaled, weights were assigned to each factor based on relative importance through a pairwise comparison matrix in the GIS program IDRISI Selva (Table 10). For the purposes of this study, population was weighted the most important, followed by land use, then infrastructure, and finally economic production. The weighted factors were then applied to calculate the total vulnerability score using WLC approach. The final output displayed the relative level of 
expected loss in the area. Based on the original categorization, areas where values were greater than 0.75 were considered most vulnerable, or would experience the greatest loss from a volcanic hazard event. Similarly, values between 0.5 and 0.75 showed moderately high vulnerability, values between 0.25 and 0.49 were moderately vulnerable, and values less than 0.25 were the least vulnerable (Figure 12).

\subsection{Risk Assessment}

As stated previously, risk is the combination of the evaluation of both the hazards and vulnerability of an area. In order to combine the hazard maps generated in this study with the social and economic vulnerability into a total risk map, the three objectives were aggregated through a MCE, similar to the generation of the economic vulnerability map.

To begin, each of the three objectives were standardized from 0 to 1 , depending on the degree to which they influenced the total risk. For the ash fall hazards, the isopach maps were reclassified into 12 classes based on thickness (Table 11) and reassigned values from 0 to 1 through the use of a linear fuzzy function, where 0 indicated no ash fall and 1 indicated the thickest ash fall deposits $>3 \mathrm{~m}$. The PDCs, on the other hand, remained classified as binary, where areas impacted by the PDCs were assigned a value of 1 and all other areas were assigned a value of 0 . Additionally, the sixteen ash fallout hazard maps and two PDC hazard maps were then condensed by summing the hazards into five new maps: (1) all Lower El Cajete-type ash fallout hazards sourced at vent A, (2) all Upper El Cajete-type ash fallout hazard sourced at vent A, (3) all Lower El Cajete-type ash fallout hazards sourced at vent B, (4) all Upper El Cajetetype ash fallout hazards sourced at vent B, and (5) PDC hazards sourced at vents A and B. The condensed ash fallout hazard maps were generated by summing the four seasonal hazard maps with an equal weighting of 0.25 , which in turn caused areas where ash fallout from different 
seasons overlapped to reflect higher levels of risk. Similarly, the condensed PDC hazard map was generated by summing the two PDC maps with an equal weighting of 0.5 . The scores for social vulnerability were also reclassified from 0 to 1 through the use of a sigmoidal fuzzy function, where areas with no social vulnerability were valued at 0 , and the CDP with the highest social vulnerability was valued at 1 . Finally, due to the methodology of creating the total economic vulnerability map, the scores for economic vulnerability were already classified from 0 to 1 .

In order to create the final risk maps, each of the five new hazard maps were then summed with the social and economic vulnerability maps through a weighted linear combination. The weights assigned to each map were determined through a pairwise comparison of the three objectives, where hazards were given the most weight, while social and economic vulnerability were equally weighted (Table 12). Using this weighting each hazard map was aggregated with the social and economic vulnerability maps to generate a total of five risk maps as shown in Figures 13 and 14. 


\section{RESULTS}

The SoVI and economic vulnerability assessment provide detailed information on the vulnerability of the study area. The SoVI shows that when comparing the 55 CDPs within the study site, 16 CDPs demonstrate high vulnerability, 27 demonstrate medium vulnerability, and 12 demonstrate low vulnerability. From mapping the SoVI, it is clear that the least vulnerable CDPs are primarily concentrated in the southeast of the study area, while CDPs with moderate vulnerability are focused in the northeast of the region (Figure 10). CDPs with standard deviations demonstrating high vulnerability, however, are concentrated in the northeast and southwest of the study area. While all communities should be prepared in the case of a volcanic hazard, it is clear from the SoVI that those communities with high vulnerability, including, Tesuque Pueblo, San Jose, Chimayo, Chili, Ohkay Owingeh, Pena Blanca, Santa Clara, Cochiti, Hernandez, Cuartelez, Zia Pueblo, San Felipe Pueblo, Sana Cruz, Santo Domingo Pueblo, Pueblito, and Cundiyo, would benefit most from resources for improving the communities' ability to respond to and recover from hazards. From the economic vulnerability assessment (Figure 11), given that population is weighted with the most importance, all of the communities mapped by the CDPs register with at least moderate vulnerability. Those communities with greater amounts of infrastructure and economic production show the highest levels of vulnerability, including areas such as Santa Fe, Los Alamos, White Rock and Espanola, and should expect the greatest economic loss should a hazard impact them. All other areas in the study site, where CDPs are not located show predominately low vulnerability, solely influenced by road type and forested and 'other' land use.

The hazard simulations indicate ash fallout would be the most widely dispersed of the three hazard types directed south and southeast of the caldera, and dispersing ash as far as $50 \mathrm{~km}$ 
from the source, depending on the seasonal variations in wind speed considered (Figures 5 and 6). In evaluating the ash fallout risk maps, the Lower El Cajete-type eruptions when sourced at predicted vent A impact several CDPs including Los Alamos, White Rock, La Cueva, Jemez Springs, Cochiti, Cochiti Lake, Santa Clara Pueblo, La Mesilla, San Ildefonso Pueblo, El Rio Rancho, Jacona, Jaconita, Pojoaque, Cuyamungue, and Cuyamungue Grant. Each of the CDPs effected by this type of eruption are estimated to be impacted with ash fall $>3 \mathrm{~m}$ at Los Alamos, White Rock, Jemez Springs, and La Cueva to as little as 1-5 mm at CDPs farther east such as Jacona, Jaconita, Pojoaque, Cuyamungue, and Cuyamungue. The vulnerability shows that the majority of the area affected would be low vulnerability forested areas, however, as expected the CDPs would suffer much greater loss, especially areas such as Los Alamos and White Rock which show the highest risk and greatest economic vulnerability of the entire affected area and lie in the midst of the highest risk area for ash fall deposits. When Upper El Cajete-type eruptions are sourced at predicted vent A, significantly fewer CDPs are impacted, limited to: Los Alamos, White Rock, San Ildefonso Pueblo, La Cueva, and Jemez Springs. During this type of eruption, the CDPs are most likely to be impacted by thinner ash fall deposits, only reaching as great as $2 \mathrm{~m}$ at La Cueva and ranging from $1 \mathrm{~m}$ to as little as 1-5 $\mathrm{mm}$ at the other CDPs. Due to the smaller deposits of ash, less destruction would be expected than with the previous eruption, and therefore CDPs such as Los Alamos and White Rock are considered to be at slightly lower risk than before. Additionally, a smaller area of forest would also be disturbed by this distribution of ash fall as compared with the previous eruption. When the Lower El Cajete-type eruptions are sourced at predicted vent B, a significantly greater number of CDPs are impacted than from either of the eruptions at vent A. In addition to the CDPs impacted by the Lower-type eruption at A, Tesuque Pueblo, Peak Place, Tesuque, Santa Fe, Agua Fria, La Cienega, 
Ponderosa, Canon, and Pena Blanca are also affected by the eruption from vent B. As a result, the risk associated with this type of eruption and vent location is the most significant, impacting the most CDPs and including the most high vulnerability places such as White Rock, Santa Fe, Agua Fria, and La Cienega. Interestingly, when the Upper El Cajete-type eruptions are sourced at predicted vent $\mathrm{B}$, this hazard shows the least destructive potential, or lowest risk, of all of the ash fallout hazards. Ash fall is limited to $1-5 \mathrm{~cm}$ at Cochiti Lake, $1 \mathrm{~m}-1 \mathrm{~mm}$ at White Rock, and $1 \mathrm{~cm}-5 \mathrm{~mm}$ at La Cienega, Agua Fria, and Santa Fe. Accordingly, White Rock, with the greatest economic vulnerability, is at the highest risk for this type of hazard, while most of the rest of the area shows lower risk, primarily consisting of forested and 'other' land types.

Unlike ash fall, the PDCs are contained to within 9 to $10 \mathrm{~km}$ of the vents, due to the nature of the hazard and parameters considered. As a result, La Cueva, which lies in a valley to the southeast of vent A, is the only CDP affect by the PDC hazard (Figure 14). Considering the economic vulnerability and the fact that the PDC would obliterate this town, the loss of La Cueva would produce the most significant economic loss of the area affected; the majority of the rest of the area affected would be low risk, only consisting of forest. However, as shown by the PDC calibrations, in the event of a lower collapse height and/or smaller friction angle, PDCs may impact more communities, also reaching Jemez Springs Village, farther south of La Cueva.

Lava flow simulations are the least threatening of all of the hazards, contained to within 2 $\mathrm{km}$ from the vent having minimal impact when erupted from either vent A or B. Due to the scale and impact of the lava flows, they are not a concern in the final assessment, which is why risk maps were not developed for these hazards. 


\section{DISCUSSION}

Although the exact activity of a future eruption is unpredictable, validating the eruption hazard parameters of each of the hazards with the East Fork Member deposits allows for the most realistic simulations possible in estimating the extent of future volcanic hazards. The simulations, however, are limited in their precision by a number of factors. For instance, the input parameters in the hazard models that are defined by the size and style of the eruption were constrained purely on the known extent of the deposits. However, over the past 55 ka the deposits, specifically the El Cajete Pyroclastic Beds and Battleship Rock Ignimbrite, have been modified by erosion or covered by the Banco Bonito Flow. For example, isopach and isopleth maps developed by Wolff et al. (2011) are limited to exposures with thicknesses $>1 \mathrm{~m}$ and lithics $>1 \mathrm{~cm}$, respectively, even though the original extent of ash fall had to have been much greater. From these maps Wolff et al. (2011) calculated the eruption column heights and volumes, which were used for parameters in the ash fall simulations in this study. Although these are the most current estimations obtainable, they could only be approximated based on the mapped extent of the deposits. Additionally, given that the isopach maps only include thicknesses $>2 \mathrm{~m}$, simulated ash deposit thicknesses $<2 \mathrm{~m}$ could not be calibrated. Similarly, the PDC calibrations were constrained by the most distal exposure known of Battleship Rock Ignimbrite, although it could have potentially had a farther runout length than what is currently exposed. Furthermore, due to the unavailability of wind and topography data at $55 \mathrm{ka}$, the ash fallout simulations could only be calibrated using modern wind conditions and the PDC simulations could only be calibrated with current, post-eruption topography, limiting the accuracy with which the simulated maps were matched to the geologic and isopach maps. 
The HVRI 2006-10 SoVI is the best-known method for estimating the social vulnerability of different communities. However, due to limitations in the availability of data, not all variables considered by the HVRI 2006-10 SoVI were used in this study, which may have influenced the determination of the final components. Also, it must be understood by risk managers that the variables chosen are only considered representative of social vulnerability. In order to determine the degree to which these variable reflect each community's social vulnerability, it would be best to compare the SoVI to community surveys directly assessing their hazard preparedness, which was not feasible within the limits of this study.

The economic vulnerability assessment provides an effective way to estimate the expected loss from hazards; however, it is limited in that the categorization and ranking of each of the factors is a somewhat subjective process. The categorization and ranking of the factors would best be determined through group decision making, or by evaluating the exact cost and value of each individual element that could be impacted, however neither technique was possible in the scope of this study. Nevertheless, with the methodology presented, the selection, standardization, and ranking of the elements of concern, can easily be modified to any risk management plan.

Although there are clear limitations in modeling the hazards and vulnerability, the overall assessment allows for the first complete analysis of the volcanic risk associated with the area surrounding Valles caldera. As shown by the hazard maps, ash fall may range from $3 \mathrm{~m}$ thick deposits to as little as $1 \mathrm{~mm}$ thick deposits. Such ash fall is known to cause serious health and structural problems, as indicated by eruptions documented around the world. For instance, during volcanic eruptions, ash particles as small as 50 microns in diameter can cause a variety of health problems including, respiratory complications, eye trauma, and skin irritation (USGS, 2010). In 
addition to such health complications, ash fall deposits as little as $3 \mathrm{~mm}$ have been shown to cause serious damage to a variety of vulnerable elements, including buildings, machinery, lifelines, and agriculture. For example, ash deposits just millimeters thick can cause significant harm to water quality, increasing the turbidity, lowering the $\mathrm{pH}$, and adding harmful chemical substances to water sources (Blong, 1984; Wilson et al., 2012). Such small amounts of ash may also infiltrate wastewater management systems clogging the equipment, causing failure and shutdown, and possibly flooding (Wilcox, 1959; Blong, 1984; Wilson et al., 2012). Similarly, as little as 1-3 cm of ash may also significantly disrupt ground transportation networks. Ash may impair drivers' visibility, cause roads to become slippery, cover road markings, and abrade vehicle engines (Wilcox, 1959; USGS, 2010; Wilson et al., 2012). Additionally, depending on the building structure and ash load, ash fall may cause roof collapse, especially if wet. For instance, ash fall deposits as little as $2 \mathrm{~cm}$ was shown to cause sagging and partial collapse in some buildings during the 1994 eruption of Rabaul, however, roofs that accumulated up to $15 \mathrm{~cm}$ in ash fall during the 1991 Pinatubo eruption did not experience damage (USGS, 2010; Spence et al., 2005). It may be expected, though, from these estimates that areas such as Los Alamos, which according to the risk assessment may receive as much as $3 \mathrm{~m}$ in ash fall, should expect severe structural damage such as roof collapse. Danger from poor driving conditions and roof collapse are commonly to blame for loss of life from ash fall hazards, emphasizing that prevention and evacuation before experiencing ash fall hazards is crucial. With the risk assessment developed in this study, areas that may be impacted by ash fall hazards, especially those with areas high vulnerability, including dense road networks, buildings, and populations, need to receive proper mitigation and education strategies to prevent such severe damage to lifelines and structures, and injury and death that may result. 
Furthermore, PDCs are even more threatening to vulnerable elements than ash fall hazards since they are nearly impossible to avoid or survive unless previously evacuated. PDCs will incinerate, bury, asphyxiate, and bludgeon anything in their path (Sherrod et al., 1997). Therefore, it is also crucial to have the risk assessment in place before an eruption in order to identify the vulnerable areas that may be threatened by PDCs so that these critical areas, such as La Cueva, will be evacuated.

Although, as stated in the beginning, Valles caldera is not currently active, this risk assessment lays the foundation for risk management in the case of a future eruption. Furthermore, the methodology applied in this study may be transferred to any area, including active volcanic areas at more imminent risk, such as Mt. Unzen, Japan, or Fuego and Pacaya, Guatemala. Considering the flexibility of the methodology applied in this study, the factors and objectives presented here may be easily modified to best suit the characteristics of any volcanically active area, but no matter, developing a detailed risk assessment through the multicriteria evaluation of the social and economic vulnerability with hazard predictions may help to advise decision makers in difficult situations, such as allocating resources for hazard prevention and evacuation, which in turn will help to reduce the cost of damage and loss of life from hazards such as ash fall and PDCs. 


\section{CONCLUSIONS}

This study presented one of the first full volcanic risk assessments of the Valles caldera area, assessing both the potential hazard distributions and the social and economic vulnerability of the area. Rather than generating hazard maps based solely on past deposits, a new technique was used to generate hazard maps by simulating different volcanic hazards grounded on past deposits at predicted future vent locations. The social and economic vulnerability assessments in this study, although adapted from established methods, provided a detailed analysis of the level of hazard preparedness of each community as well as the level of expected economic loss, which has never before been analyzed specifically for this region. Together, the summation of the hazards and social and economic vulnerability into a total risk map presented a robust analysis of the risk the Valles caldera area may be faced with in the event of a volcanic hazard similar to those from the East Fork Member eruptions. This assessment provides not only a new methodology for evaluating risk, but a foundation for risk management in north-central New Mexico, should Valles caldera become active once again. 


\section{TABLES}

Table 1. Parameters for ash fallout.

\begin{tabular}{|lcc|}
\hline \multicolumn{1}{|c}{ Parameter } & Lower El Cajete & Upper El Cajete \\
\hline Volume $\left(\mathrm{km}^{3}\right)$ & 30.5 & 0.52 \\
Column Height $(\mathrm{m})$ & 36000 & 25000 \\
A Parameter & 4 & 4 \\
Particle Size & & \\
$\quad$ Mean $(\phi)$ & -4.8 & -5.1 \\
$\quad$ Standard Deviation $(\phi)$ & 1.0 & 0.7 \\
$\quad$ Minimum $(\phi)$ & -6.7 & -6.3 \\
$\quad$ Maximum $(\phi)$ & -3.2 & -3.7 \\
Particle Density $\left(\mathrm{kg} / \mathrm{m}^{3}\right)$ & & 800 \\
$\quad$ Big & 800 & 1200 \\
$\quad$ Medium & 1200 & 2380 \\
$\quad$ Small & 2380 & 3.45 \\
Drag Coefficient & 3.45 & 3000 \\
Horizontal Diffusion $\left(\mathrm{m}^{2} / \mathrm{s}\right)$ & 3000 & 12500 \\
Tropopause Height $\left(\mathrm{m}^{2}\right)$ & 12500 & 200 \\
Air Density $\left(\mathrm{kg} / \mathrm{m}^{3}\right)$ & 1.2255 & 2255 \\
Air Temperature $(\mathrm{K})$ & 288 & 0.5 \\
Vertical Step $(\mathrm{m})$ & 200 & 200 \\
Horizontal Step $(\mathrm{m})$ & 200 & \\
Fi Step & 0.5 & \\
\hline
\end{tabular}


Table 2. Wind data for January.

\begin{tabular}{|c|c|c|}
\hline Altitude (m) & Speed $(\mathrm{m} / \mathrm{s})$ & $\begin{array}{l}\text { Direction } \\
\text { (degrees) }\end{array}$ \\
\hline 2027 & 316 & 6 \\
\hline 3009 & 321 & 10 \\
\hline 4023 & 306 & 14 \\
\hline 5046 & 300 & 17 \\
\hline 6007 & 295 & 20 \\
\hline 7134 & 297 & 21 \\
\hline 7866 & 313 & 23 \\
\hline 9174 & 300 & 26 \\
\hline 10194 & 297 & 27 \\
\hline 11142 & 300 & 27 \\
\hline 12136 & 298 & 27 \\
\hline 13096 & 295 & 25 \\
\hline 14014 & 290 & 23 \\
\hline 15134 & 294 & 20 \\
\hline 16068 & 292 & 18 \\
\hline 17148 & 290 & 15 \\
\hline 18196 & 307 & 11 \\
\hline 19123 & 338 & 8 \\
\hline 20171 & 12 & 7 \\
\hline 21089 & 30 & 7 \\
\hline 22117 & 40 & 8 \\
\hline 23129 & 53 & 10 \\
\hline 24034 & 54 & 11 \\
\hline 25034 & 63 & 11 \\
\hline 26123 & 106 & 13 \\
\hline 27201 & 59 & 14 \\
\hline 28136 & 55 & 16 \\
\hline 29132 & 54 & 16 \\
\hline 30288 & 103 & 17 \\
\hline 31040 & 97 & 17 \\
\hline 31975 & 80 & 18 \\
\hline 32690 & 73 & 24 \\
\hline
\end{tabular}


Table 3. Wind data for April.

\begin{tabular}{|c|c|c|}
\hline Altitude (m) & Speed $(\mathrm{m} / \mathrm{s})$ & $\begin{array}{l}\text { Direction } \\
\text { (degrees) }\end{array}$ \\
\hline 1961 & 330 & 5 \\
\hline 3038 & 278 & 9 \\
\hline 4070 & 273 & 12 \\
\hline 5058 & 269 & 16 \\
\hline 6017 & 273 & 18 \\
\hline 7175 & 286 & 21 \\
\hline 7890 & 282 & 22 \\
\hline 9210 & 284 & 24 \\
\hline 10201 & 283 & 28 \\
\hline 11000 & 267 & 27 \\
\hline 12105 & 266 & 28 \\
\hline 13114 & 261 & 25 \\
\hline 14045 & 261 & 23 \\
\hline 15110 & 262 & 21 \\
\hline 16079 & 261 & 19 \\
\hline 17187 & 253 & 14 \\
\hline 18222 & 252 & 10 \\
\hline 19136 & 306 & 6 \\
\hline 20171 & 350 & 5 \\
\hline 21079 & 339 & 5 \\
\hline 22086 & 16 & 5 \\
\hline 23147 & 343 & 5 \\
\hline 24051 & 348 & 4 \\
\hline 25047 & 328 & 6 \\
\hline 26146 & 337 & 6 \\
\hline 27153 & 310 & 7 \\
\hline 28055 & 314 & 9 \\
\hline 29121 & 287 & 9 \\
\hline 30229 & 296 & 11 \\
\hline 31031 & 288 & 12 \\
\hline 31990 & 271 & 12 \\
\hline 32939 & 257 & 13 \\
\hline 34105 & 265 & 14 \\
\hline
\end{tabular}


Table 4. Wind data for July.

\begin{tabular}{|c|c|c|}
\hline Altitude (m) & Speed $(\mathrm{m} / \mathrm{s})$ & $\begin{array}{l}\text { Direction } \\
\text { (degrees) }\end{array}$ \\
\hline 1976 & 322 & 4 \\
\hline 3050 & 320 & 5 \\
\hline 4092 & 27 & 6 \\
\hline 5119 & 55 & 7 \\
\hline 6082 & 22 & 6 \\
\hline 7055 & 37 & 6 \\
\hline 7932 & 62 & 5 \\
\hline 9100 & 32 & 6 \\
\hline 9966 & 29 & 6 \\
\hline 11078 & 25 & 8 \\
\hline 12269 & 357 & 9 \\
\hline 13115 & 1 & 8 \\
\hline 14130 & 1 & 8 \\
\hline 15137 & 41 & 6 \\
\hline 16091 & 84 & 6 \\
\hline 16976 & 50 & 6 \\
\hline 18136 & 77 & 8 \\
\hline 19063 & 84 & 10 \\
\hline 20100 & 89 & 11 \\
\hline 21051 & 89 & 13 \\
\hline 22066 & 89 & 13 \\
\hline 23102 & 88 & 14 \\
\hline 24122 & 90 & 15 \\
\hline 25004 & 87 & 15 \\
\hline 26051 & 89 & 16 \\
\hline 27075 & 86 & 17 \\
\hline 28067 & 88 & 19 \\
\hline 29105 & 87 & 22 \\
\hline 30251 & 91 & 22 \\
\hline 31197 & 90 & 23 \\
\hline 32066 & 89 & 24 \\
\hline 33047 & 90 & 25 \\
\hline 33852 & 87 & 28 \\
\hline
\end{tabular}


Table 5. Wind data for October.

\begin{tabular}{|c|c|c|}
\hline Altitude (m) & Speed $(\mathrm{m} / \mathrm{s})$ & $\begin{array}{l}\text { Direction } \\
\text { (degrees) }\end{array}$ \\
\hline 1987 & 350 & 6 \\
\hline 3030 & 287 & 10 \\
\hline 4063 & 284 & 13 \\
\hline 5004 & 282 & 16 \\
\hline 6001 & 289 & 18 \\
\hline 7212 & 279 & 21 \\
\hline 7925 & 282 & 22 \\
\hline 9247 & 281 & 25 \\
\hline 10127 & 275 & 27 \\
\hline 11008 & 280 & 31 \\
\hline 12115 & 281 & 34 \\
\hline 13162 & 282 & 32 \\
\hline 14066 & 282 & 29 \\
\hline 15105 & 283 & 26 \\
\hline 16148 & 284 & 24 \\
\hline 17166 & 285 & 19 \\
\hline 18198 & 291 & 13 \\
\hline 19092 & 283 & 8 \\
\hline 20132 & 285 & 8 \\
\hline 21026 & 277 & 8 \\
\hline 22097 & 239 & 7 \\
\hline 23083 & 302 & 6 \\
\hline 24080 & 338 & 6 \\
\hline 25039 & 7 & 6 \\
\hline 26162 & 359 & 6 \\
\hline 27195 & 182 & 5 \\
\hline 28049 & 334 & 6 \\
\hline 29026 & 7 & 7 \\
\hline 30234 & 25 & 7 \\
\hline 31004 & 19 & 7 \\
\hline 32034 & 20 & 5 \\
\hline 32784 & 33 & 6 \\
\hline
\end{tabular}


Table 6. Parameters for calibrating pyroclastic density currents.

\begin{tabular}{|cc|}
\hline Collapse Height $(\mathbf{m})$ & Collapse Equivalent Angle (degrees) \\
\hline 1500 & 10.6 \\
1000 & 7.1 \\
500 & 3.6 \\
\hline
\end{tabular}


Table 7. Variables for social vulnerability assessment.

\begin{tabular}{|c|c|c|}
\hline Variables & Variable Description & $\begin{array}{c}\text { Increases or } \\
\text { Decreases } \\
\text { SVI }\end{array}$ \\
\hline QAGEDEP & Percent under 5 years and over 65 years of age & + \\
MEDAGE & Median age & - \\
QFEMALE & Percent females & + \\
QBLACK & Percent African American & + \\
QASIAN & Percent Asian & + \\
QHISP & Percent Hispanic & + \\
QNATAM & Percent Native American & + \\
QMOHO & Percent mobiles homes & + \\
QRENTER & Percent of renters & + \\
QNOAUTO & Percent of housing units with no car & - \\
MDHSEVAL & Median house value & - \\
MDRENT & Median Rent & + \\
QFEMLBR & Percent female participation in labor force & + \\
QCVLUN & Percent civil unemployment & + \\
QSERV & Percent in service industry & + \\
QEXTRACT & Percent employment in extractive industries & + \\
QRICH & Percent of households earning over \$200,000 & - \\
QSSBEN & Percent social security beneficiaries & + \\
PERCAP & Per capita income & + \\
QPOVTY & Percent poverty & + \\
QFHH & Percent female headed household & + \\
PPUNIT & Average household size & + \\
QED12LESS & Percent with less than 12 & grade education \\
QESL & Percent speaking English “less than very well” & + \\
& & + \\
\hline
\end{tabular}


Table 8. Variable loadings for components for social vulnerability index.

\begin{tabular}{|c|c|c|}
\hline Component & Dominant Variables & Loading \\
\hline & MEDAGE & -0.583 \\
Ethnicity (Native American) & QHISP & -0.681 \\
$(12.5 \%)$ & QNATAM & 0.845 \\
& QFHH & 0.647 \\
& PPUNIT & 0.789 \\
\hline & QAGEDEP & 0.741 \\
Age & QNOAUTO & 0.592 \\
$(10.6 \%)$ & QFEMLBR & -0.712 \\
& QSSBEN & 0.796 \\
\hline Class & QMOHO & 0.632 \\
$(9.5 \%)$ & QSERV & 0.678 \\
& QED12LESS & 0.639 \\
\hline Poverty and Unemployment & QRENTER & 0.691 \\
$(8 \%)$ & MDHSEVAL & 0.538 \\
& MDRENT & 0.638 \\
\hline Wealth & QASIAN & 0.721 \\
$(6.8 \%)$ & MDRENT & 0.558 \\
\hline Race (African American) & QEXTRCT & 0.791 \\
$(4.7 \%)$ & QRICH & 0.821 \\
\hline Gender & QFEMALE & 0.853 \\
\hline Wealth and Extractive Employment & QBLACK & -0.880 \\
\hline & & \\
\hline & & \\
\hline
\end{tabular}


Table 9. Categorization of factors for economic vulnerability.

\begin{tabular}{|c|c|c|c|c|}
\hline Factor & $\begin{array}{c}\text { Low } \\
\text { Vulnerability } \\
(\mathbf{0 . 2 5 )}\end{array}$ & $\begin{array}{c}\text { Moderate } \\
\text { Vulnerability } \\
(0.5)\end{array}$ & $\begin{array}{c}\text { Moderately-High } \\
\text { Vulnerability } \\
(\mathbf{0 . 7 5 )}\end{array}$ & $\begin{array}{c}\text { High } \\
\text { Vulnerability } \\
\text { (1) }\end{array}$ \\
\hline Population & $\begin{array}{l}<1,500 \\
\text { People }\end{array}$ & $\begin{array}{c}1,500-6,000 \\
\text { People }\end{array}$ & $\begin{array}{c}6,000-13,000 \\
\text { People }\end{array}$ & $>13,000$ People \\
\hline $\begin{array}{l}\text { Land Use } \\
\text { Infrastructure }\end{array}$ & Other & Forestry & Agriculture & Urban \\
\hline $\begin{array}{l}\text { Housing } \\
\text { Units }\end{array}$ & $<800$ Units & $\begin{array}{c}800-4,000 \\
\text { Units }\end{array}$ & $\begin{array}{c}4,000-6,000 \\
\text { Units }\end{array}$ & $>6,000$ Units \\
\hline Road Type & Local & Collectors & Arterials & Freeways \\
\hline Schools & 1 per CDP & 2 per CDP & $3-15$ per $\mathrm{CDP}$ & $>15$ per $\mathrm{CDP}$ \\
\hline $\begin{array}{l}\text { Medical } \\
\text { Facilities }\end{array}$ & 1 per CDP & 2 per CDP & 3-6 per CDP & 7-8 per CDP \\
\hline $\begin{array}{l}\text { Economic } \\
\text { Production }\end{array}$ & $<\$ 15,000,000$ & $\begin{array}{l}\$ 15,000,000- \\
\$ 30,000,000\end{array}$ & $\begin{array}{l}\$ 30,000,000- \\
\$ 45,000,000\end{array}$ & $>\$ 45,000,000$ \\
\hline
\end{tabular}


Table 10. Pairwise comparison matrix for economic vulnerability.

\begin{tabular}{|c|c|c|c|c|c|c|c|c|}
\hline & Population & Land Use & $\begin{array}{l}\text { Housing } \\
\text { Units }\end{array}$ & $\begin{array}{l}\text { Road } \\
\text { Type }\end{array}$ & Schools & $\begin{array}{l}\text { Medical } \\
\text { Facilities }\end{array}$ & $\begin{array}{c}\text { Econ } \\
\text { Production }\end{array}$ & Weight \\
\hline Population & 1 & - & - & - & - & - & - & 0.4174 \\
\hline Land Use & $1 / 3$ & 1 & - & - & - & - & - & 0.2146 \\
\hline Housing Units & $1 / 5$ & $1 / 3$ & 1 & - & - & - & - & 0.0833 \\
\hline Road Type & $1 / 5$ & $1 / 3$ & 1 & 1 & - & - & - & 0.0833 \\
\hline Schools & $1 / 5$ & $1 / 3$ & 1 & 1 & 1 & - & - & 0.0833 \\
\hline $\begin{array}{l}\text { Medical } \\
\text { Facilities }\end{array}$ & $1 / 5$ & $1 / 3$ & 1 & 1 & 1 & 1 & - & 0.0833 \\
\hline $\begin{array}{l}\text { Economic } \\
\text { Production }\end{array}$ & $1 / 7$ & $1 / 5$ & $1 / 3$ & $1 / 3$ & $1 / 3$ & $1 / 3$ & 1 & 0.0349 \\
\hline
\end{tabular}

In the pairwise comparison matrix, each of the criteria is rated relative to one another through an analytical hierarchy process. The importance of the criterion in each row is compared to the importance of the criterion of the column. The criterion may be considered extremely less important (1/9), very strongly less important (1/7), strongly less important (1/5), moderately less important (1/3), equally important (1), moderately more important (3), strongly more important (5), very strongly more important (7), or extremely more important (9) than the criterion indicated by the column. For instance, land use is considered moderately less important than land use, and therefore is assigned a value of $1 / 3$. The consistency ratio for this matrix is 0.01 , which is adequate. 
Table 11. Reclassification of ash fall hazards.

\begin{tabular}{|c|c|}
\hline $\begin{array}{c}\text { Reclassification } \\
\text { Value }\end{array}$ & Ashfall Thickness (m) \\
\hline 0 & $<0.001$ \\
1 & $0.001-0.005$ \\
2 & $0.005-0.010$ \\
3 & $0.010-0.050$ \\
4 & $0.050-0.100$ \\
5 & $0.100-0.250$ \\
6 & $0.250-0.500$ \\
7 & $0.500-0.750$ \\
8 & $0.750-1.000$ \\
9 & $1.000-2.000$ \\
10 & $2.000-3.000$ \\
11 & $>3.000$ \\
\hline
\end{tabular}

Table 12. Pairwise comparison matrix for total risk.

\begin{tabular}{|l|ccc|c|}
\cline { 2 - 5 } \multicolumn{1}{c|}{} & Hazard & $\begin{array}{c}\text { Social } \\
\text { Vulnerability }\end{array}$ & $\begin{array}{c}\text { Economic } \\
\text { Vulnerability }\end{array}$ & Weight \\
\hline Hazard & 1 & - & - & 0.600 \\
Social Vulnerability & $1 / 3$ & 1 & - & 0.200 \\
Economic Vulnerability & $1 / 3$ & 1 & 1 & 0.200 \\
\hline
\end{tabular}

As shown, the hazards are weighted the highest, while the social and economic vulnerability are equal to one another, but moderately less important than the hazards. The consistency ratio for this matrix is 0.00 , which is adequate. 


\section{FIGURES}

\section{Study Site for Risk Assessment of Valles Caldera Area}
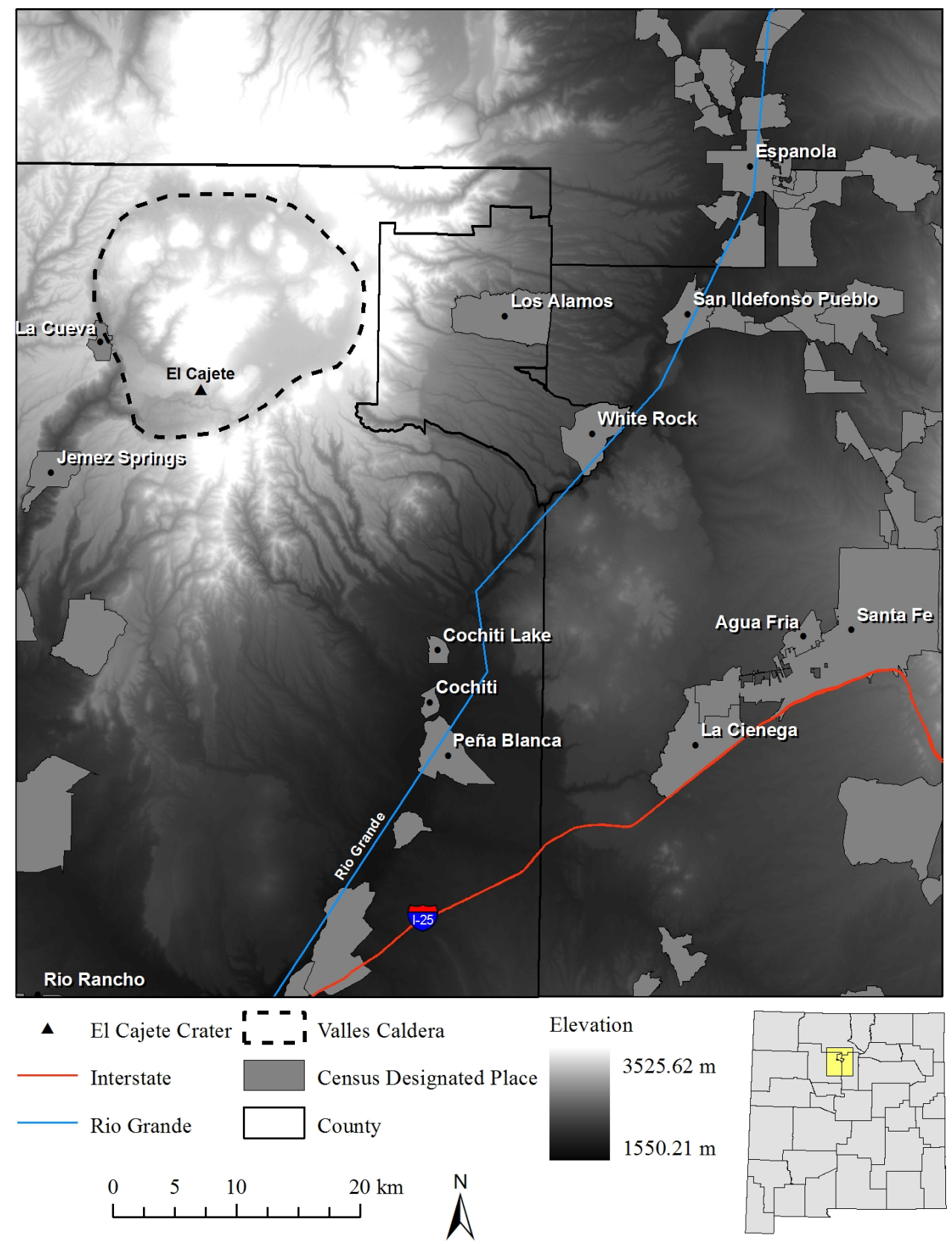

Figure 1. DEM location map of the study area including the 55 census designated places focused on in the vulnerability assessments. 


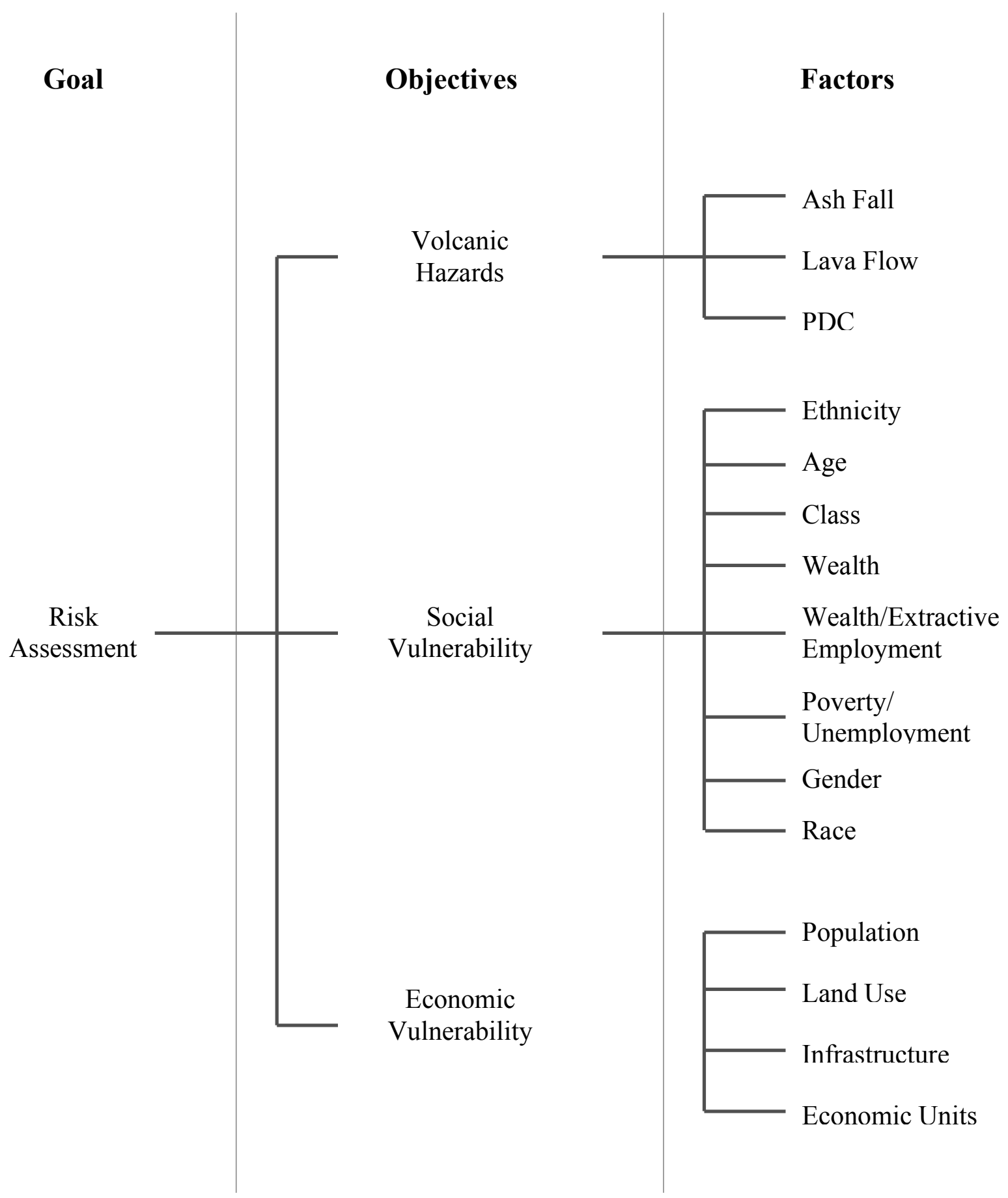

Figure 2. Conceptual framework for developing the overall risk assessment. 


\section{Vent Susceptibility Map A: As a Function of Vents, Faults, Springs, and Fumaroles}

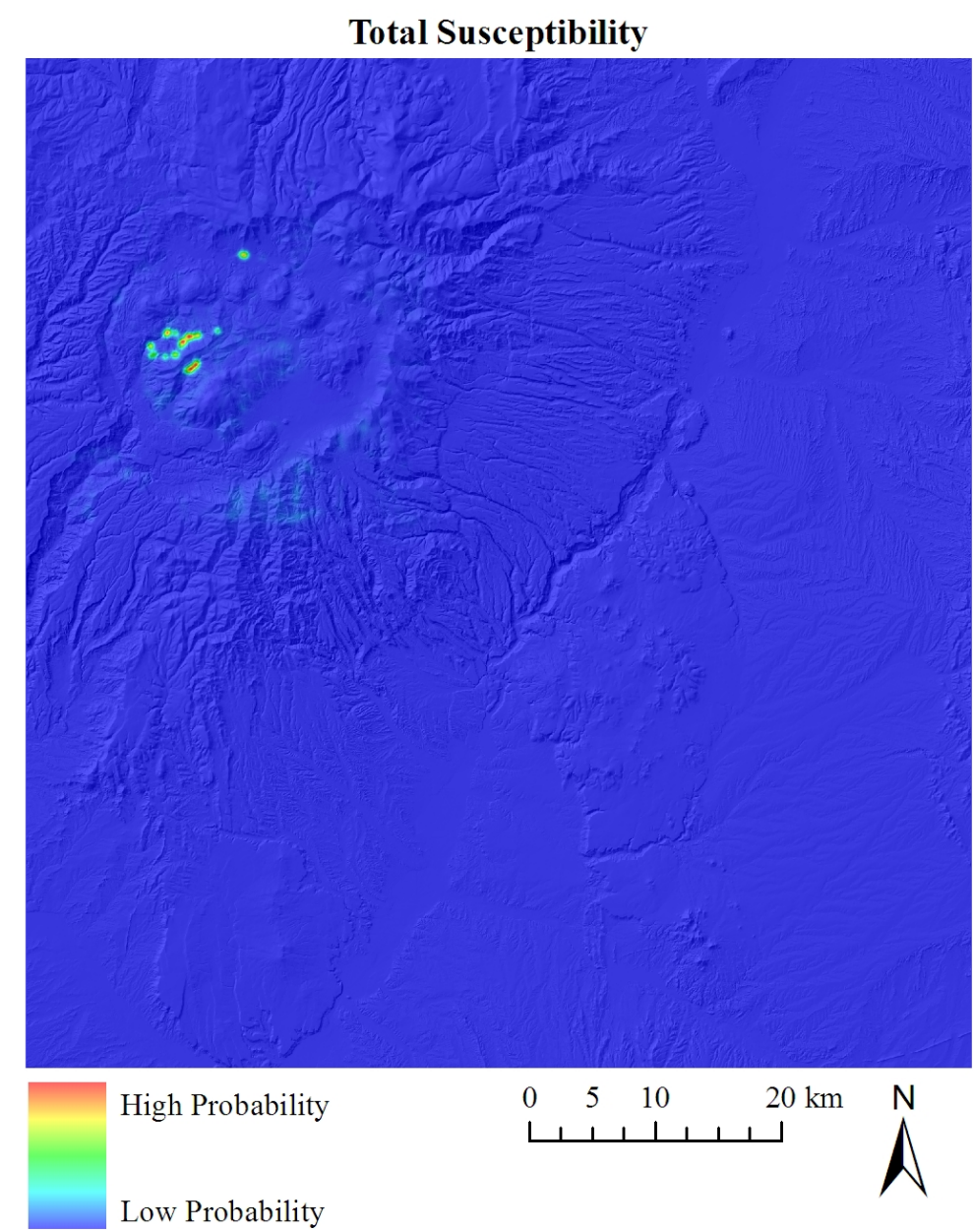

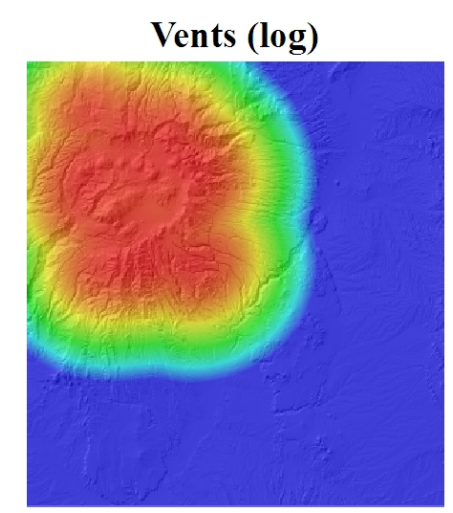

Springs (log)

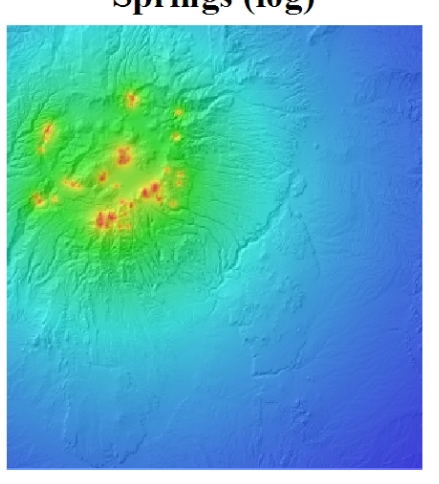

Faults (log)

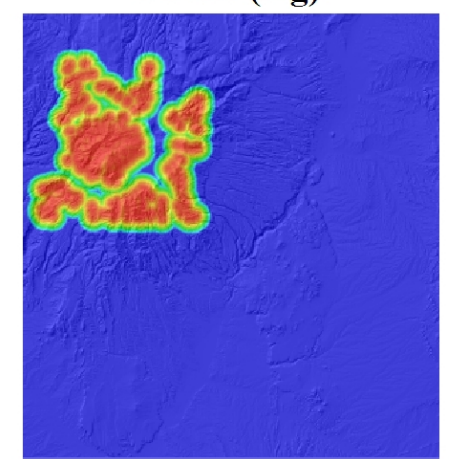

Fumaroles (log)

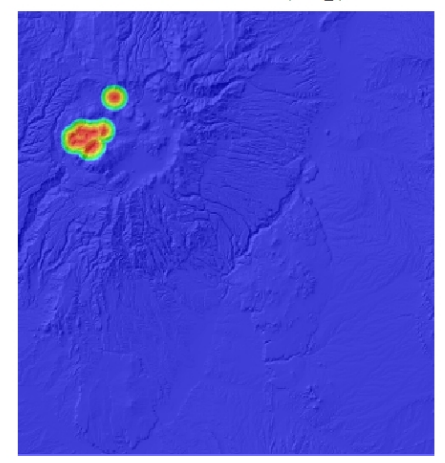

Figure 3. Vent susceptibility map generated from probability distribution of vents, faults, springs and fumaroles (left). 


\section{Vent Susceptibility Map B: As a Function of Vents and Faults}

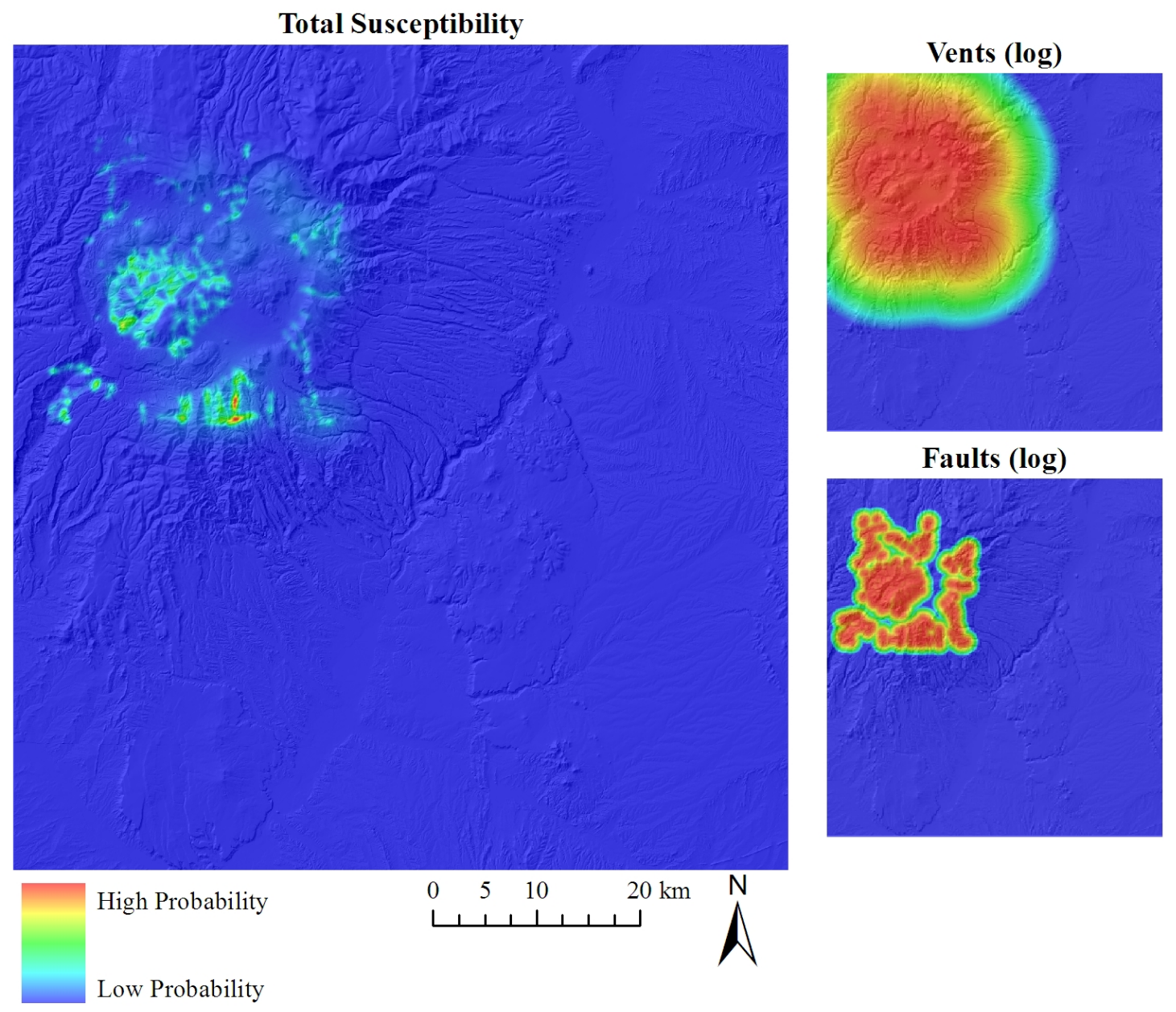

Figure 4. Vent susceptibility map generated from probability distribution of vents and faults (left). 


\section{Lower El Cajete Ash Fall Simulations at El Cajete Crater}

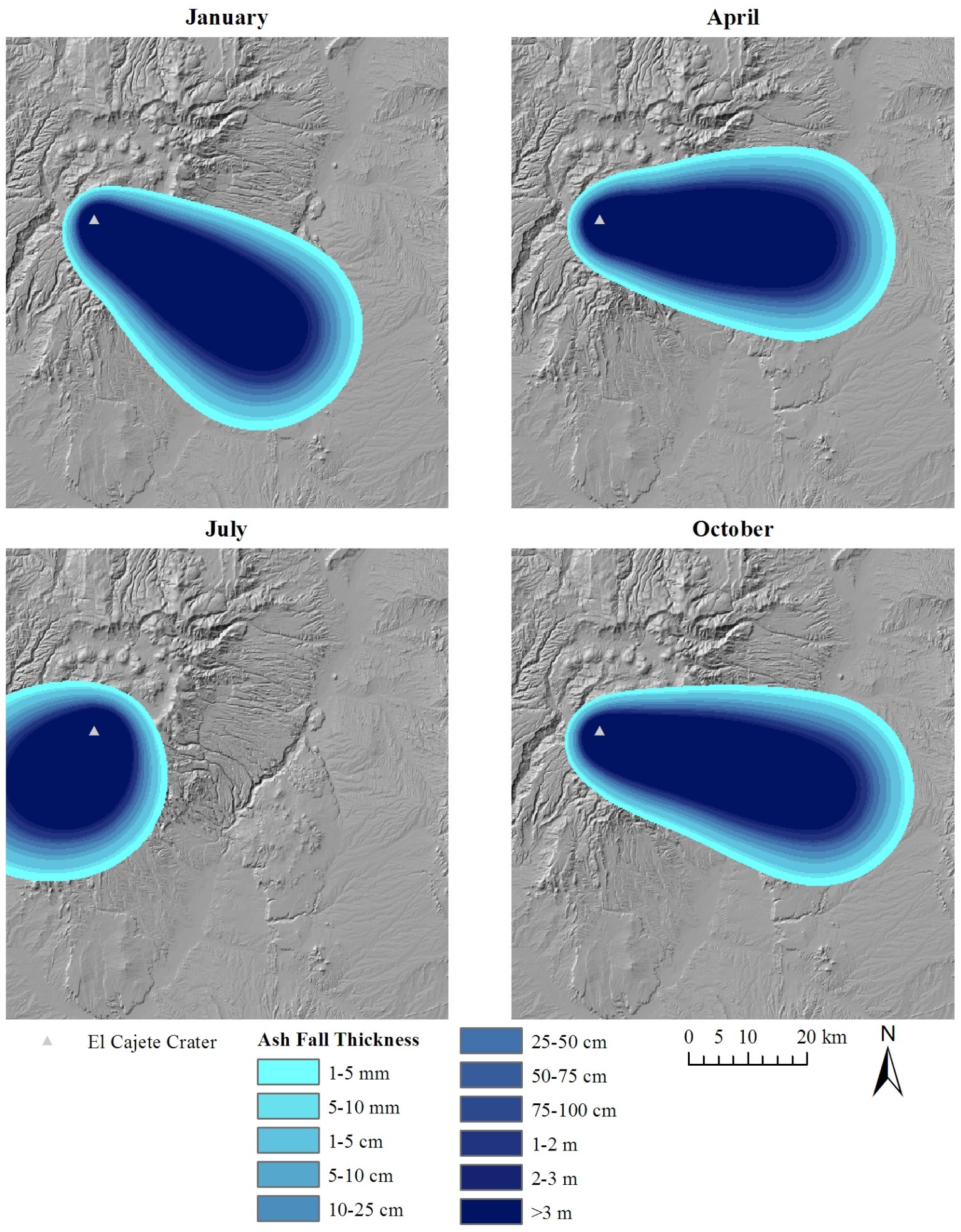

Figure 5. Maps of the Lower El Cajete calibration for each month of wind data. 


\section{Upper El Cajete Ash Fall Simulations at El Cajete Crater}

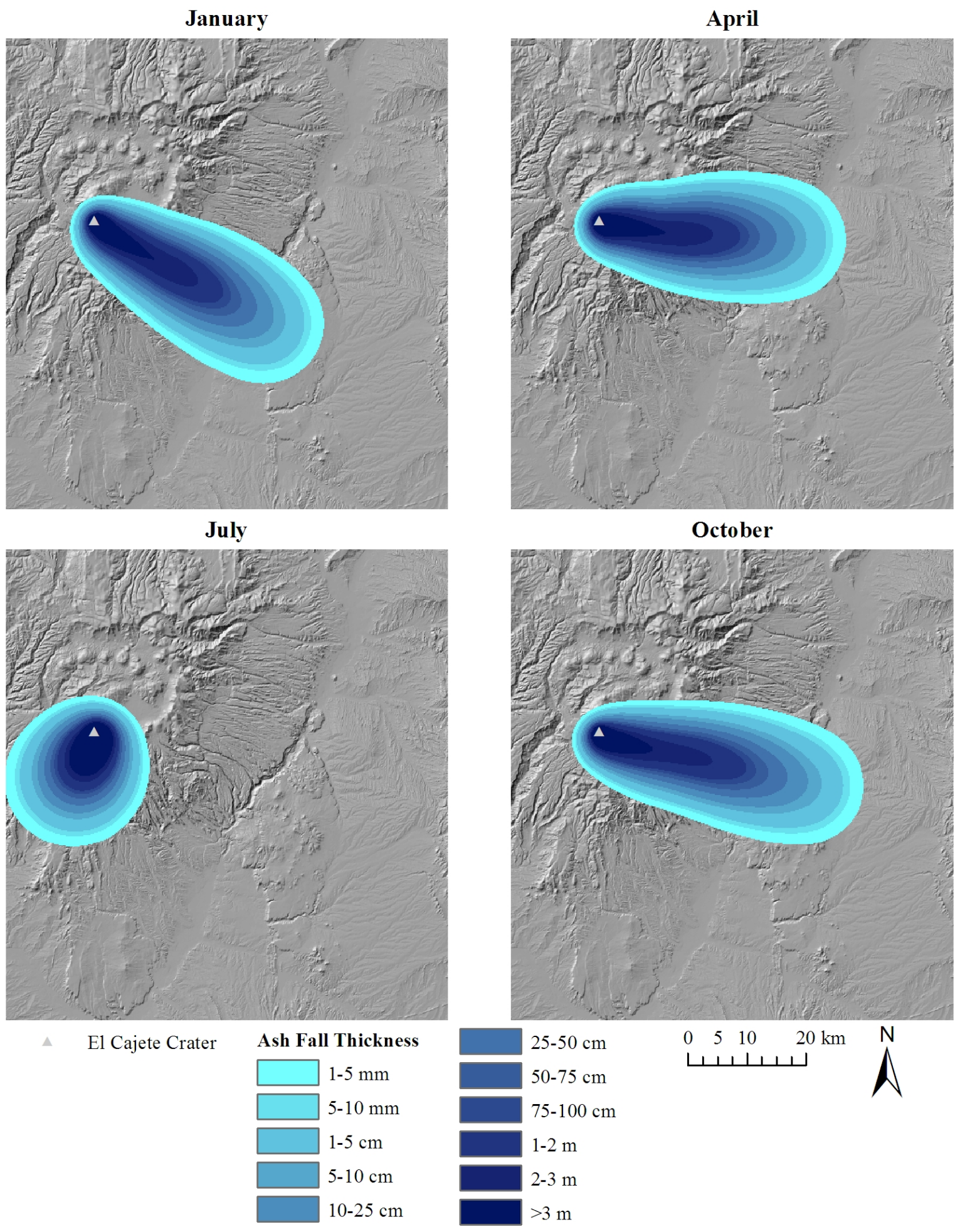

Figure 6. Maps of the Upper El Cajete calibration for each month of wind data. 


\section{Battleship Rock Ignimbrite Simulations at El Cajete Crater}
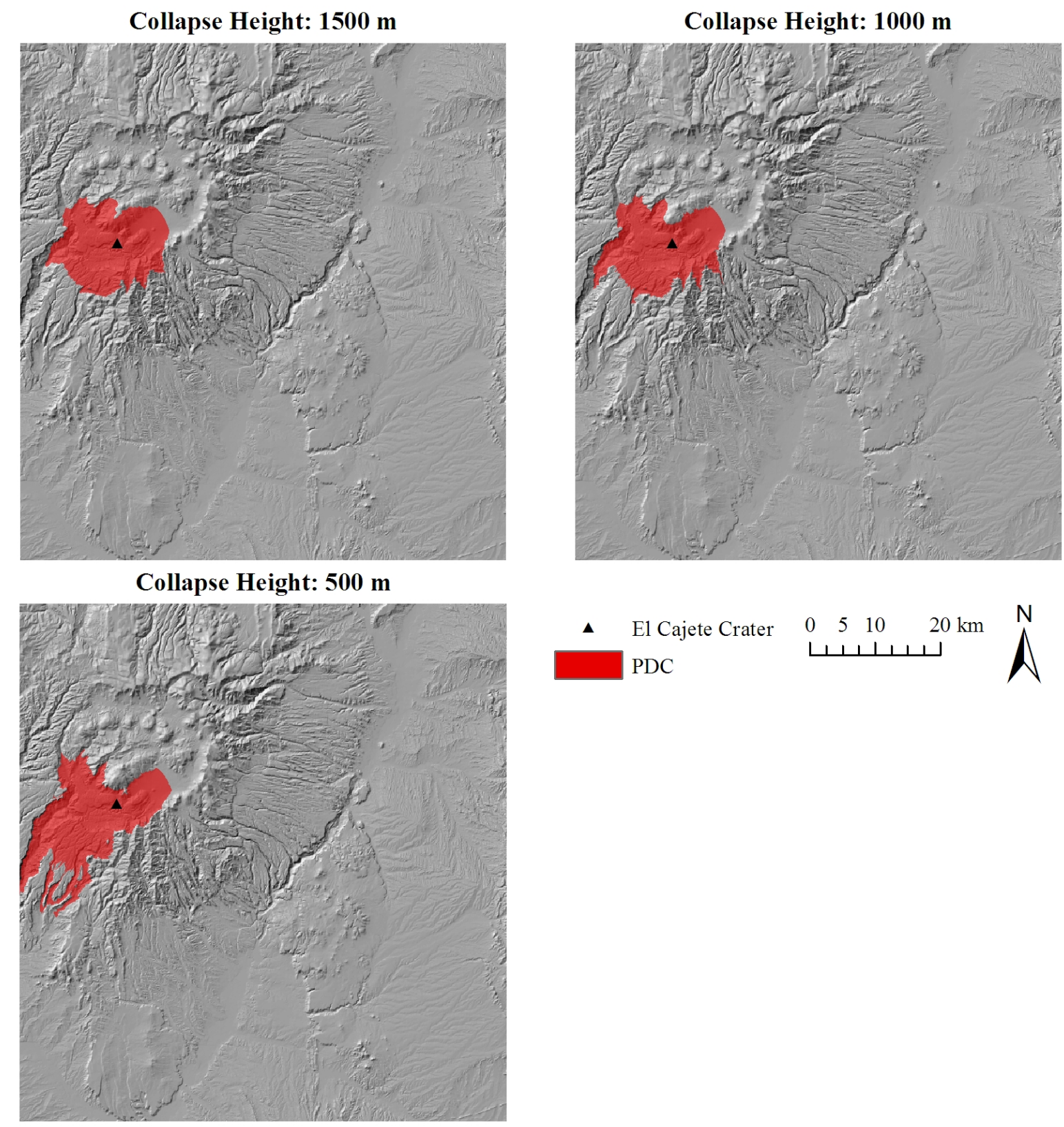

Figure 7. Maps of the Battleship Rock Ignimbrite calibration for PDCs of different collapse equivalent heights and angles. 


\section{Lava Flow Simulation at Vents $A$ and B}

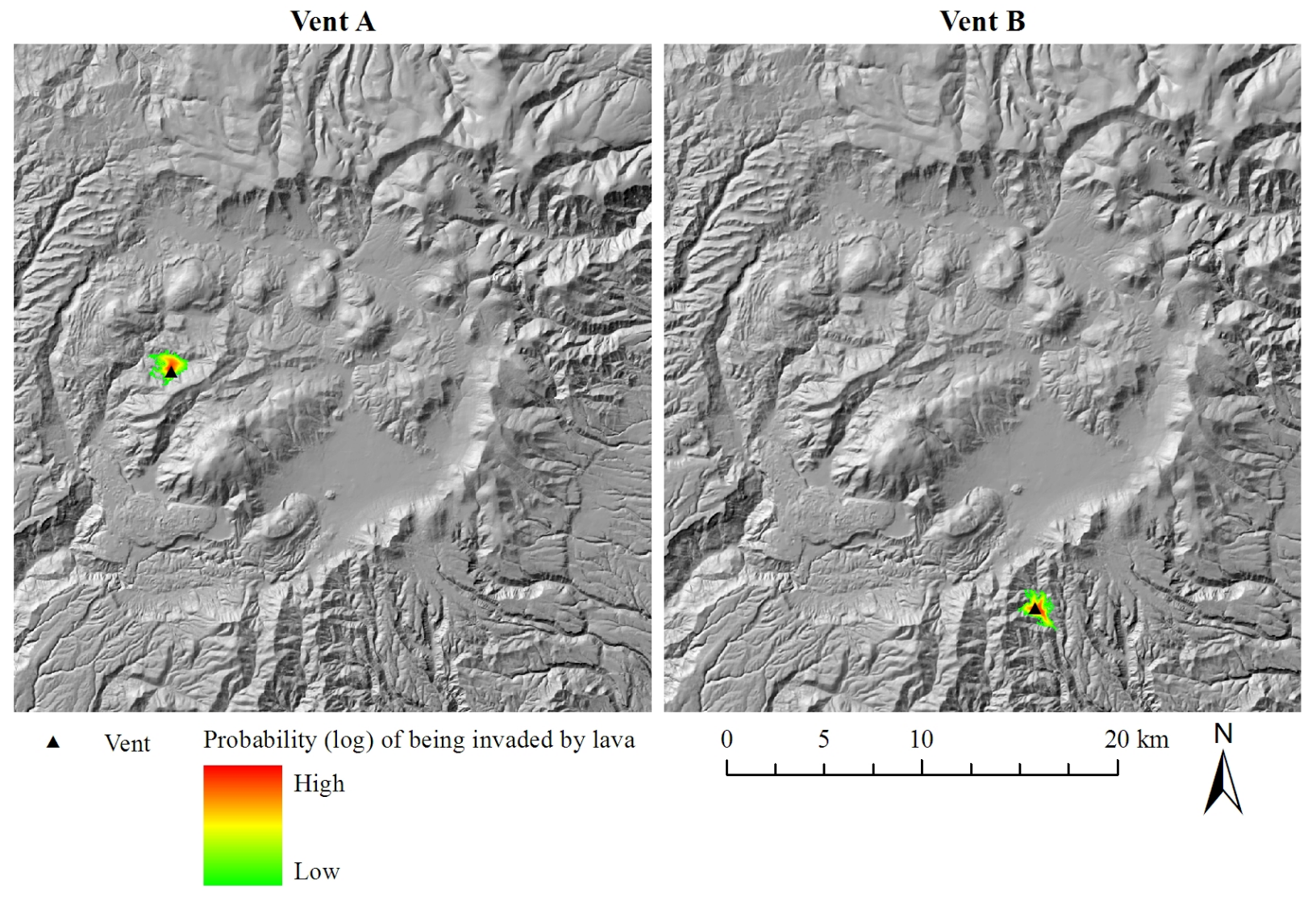

Figure 8. Maps of the lava flow simulations at vents A and B. 


\section{Standard Deviation of Prinicpal Component Scores for Social Vulnerability Indices: \\ Valles Caldera Area}
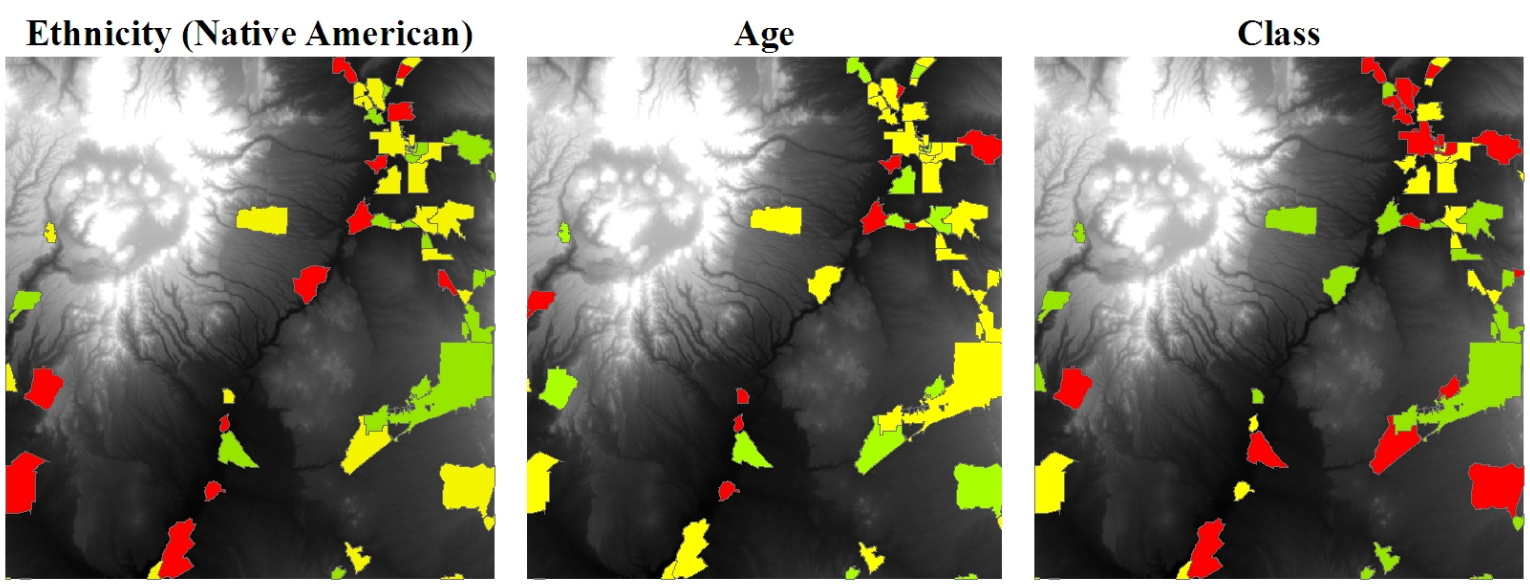

Poverty \& Unemployment
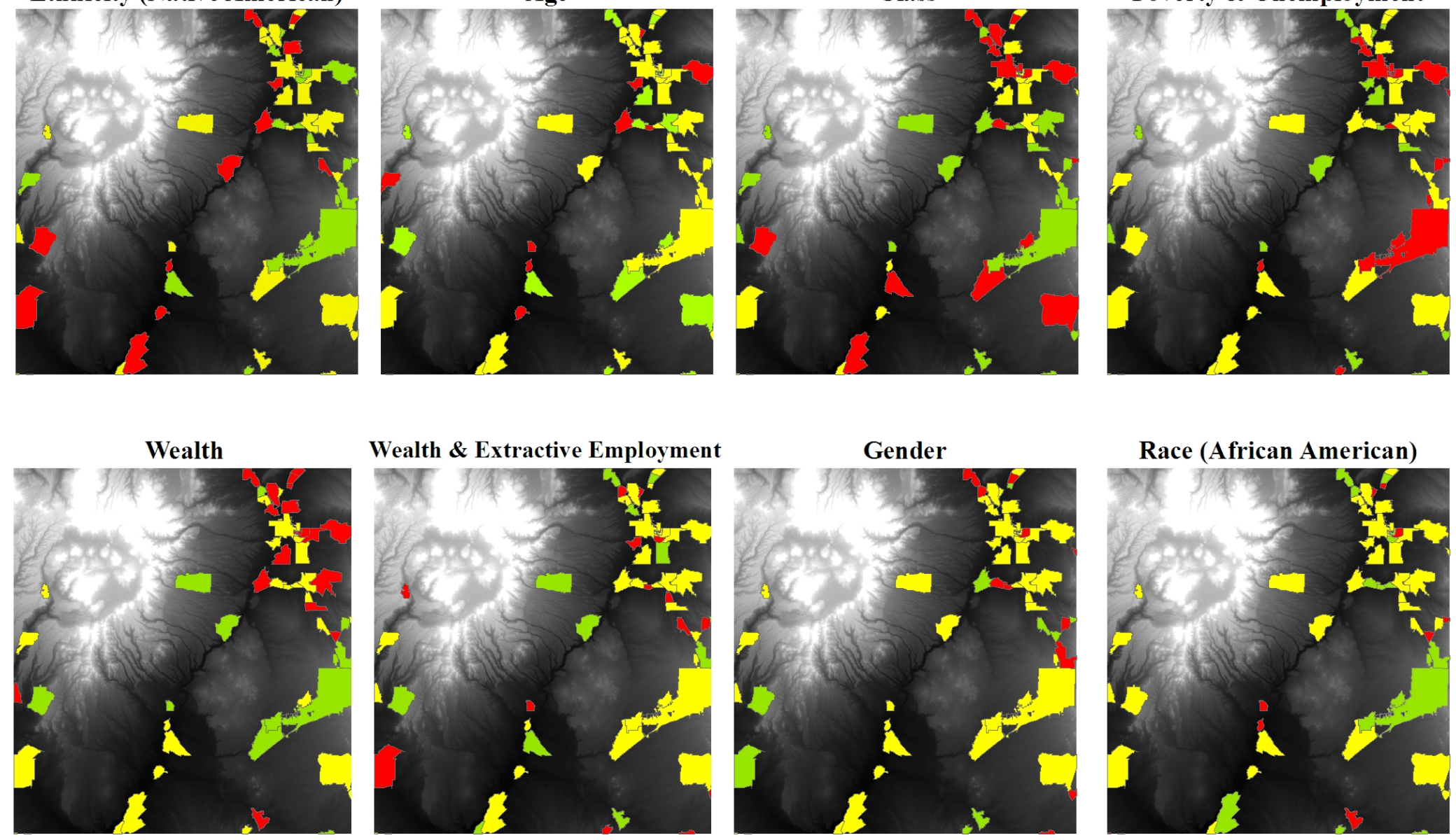

Wealth \& Extractive Employment
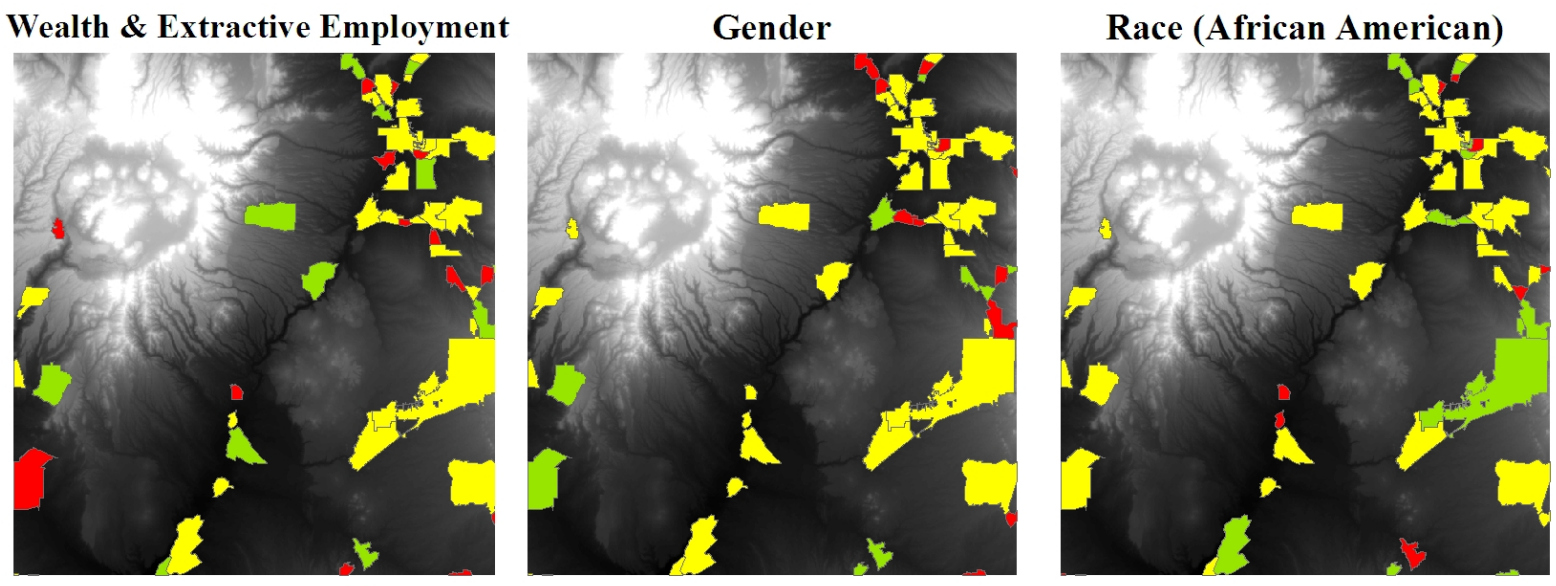

Standard Deviation

$\square$ Low $<-0.5$

$\begin{array}{lll}0 & 10 & 20\end{array}$

Moderate $-0.5-0.5$

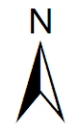

High $>0.5$

Figure 9. Individual maps of the standard deviation from the mean of principal component scores for each CDP. 


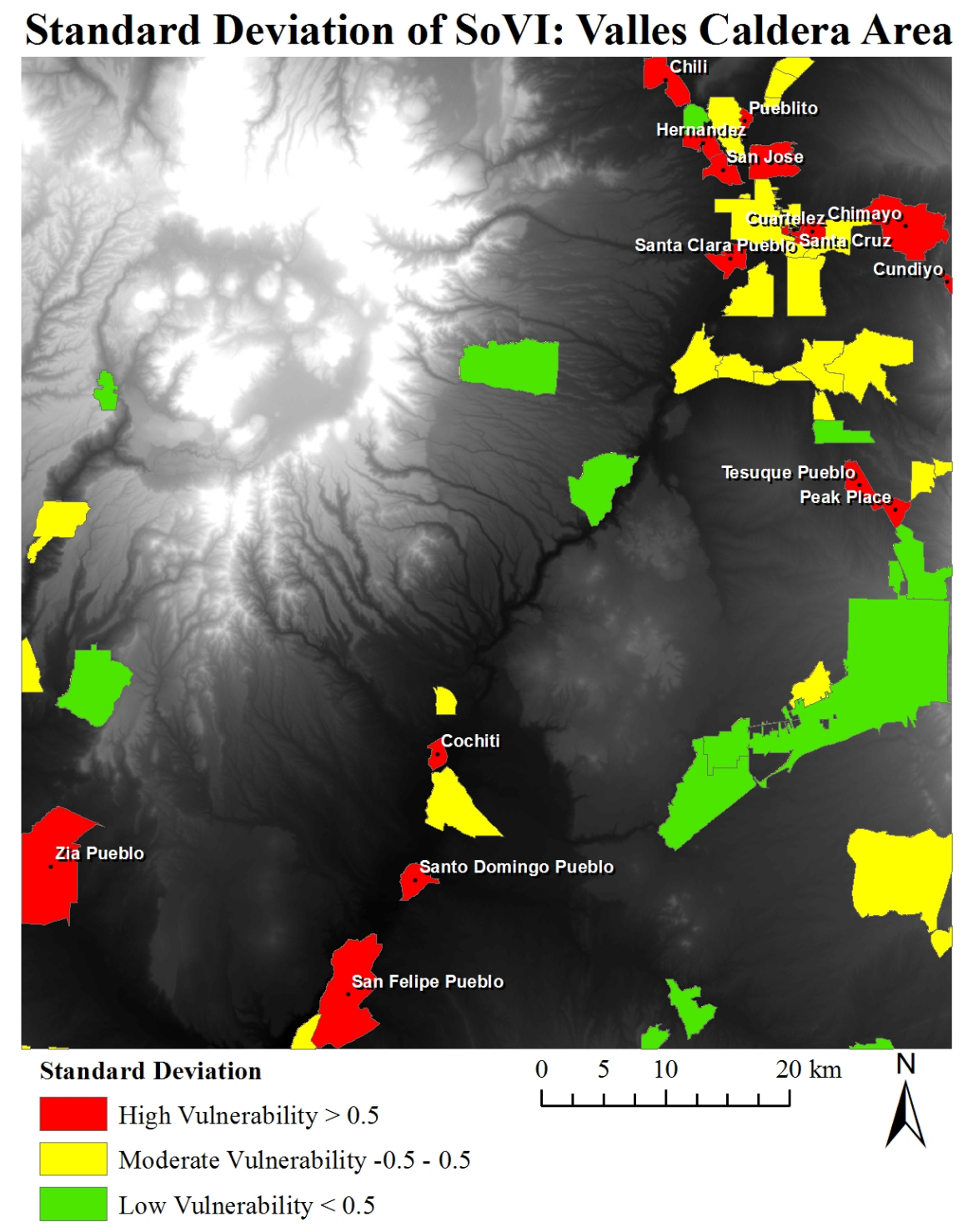

Figure 10. Map of the standard deviations from the mean of the total social vulnerability score for each CDP. 


\section{Economic Vulnerability of Individual Factors: Valles Caldera Area}
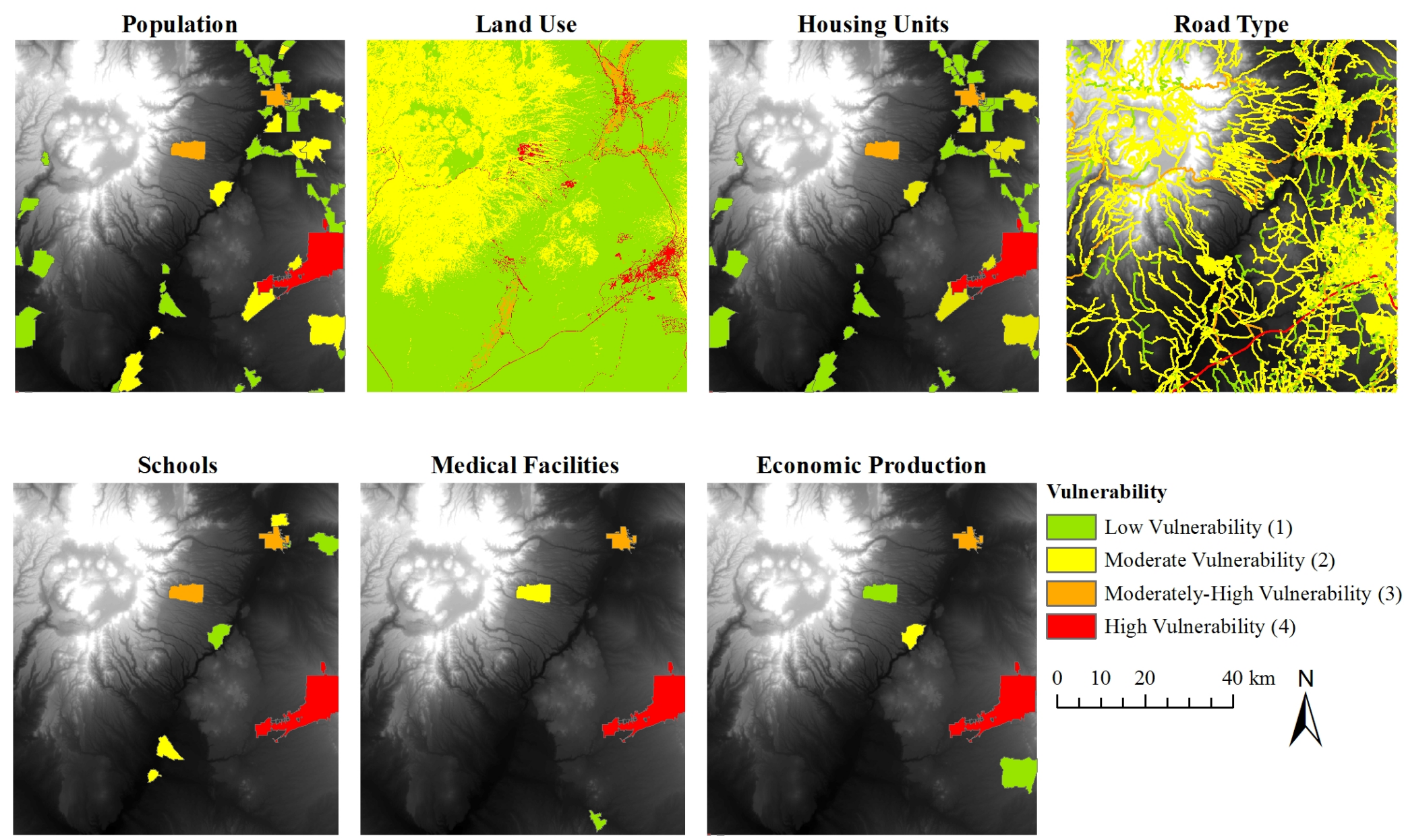

Vulnerability

$\square$ Low Vulnerability (1)

Moderate Vulnerability (2)

Moderately-High Vulnerability (3)

High Vulnerability (4)

$\begin{array}{lll}0 & 10 & 20\end{array}$

$40 \mathrm{~km} \quad \mathrm{~N}$

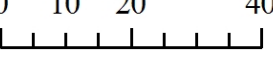

$$
N
$$

Figure 11. Individual maps of the economic vulnerability of each factor from vents A and B. 


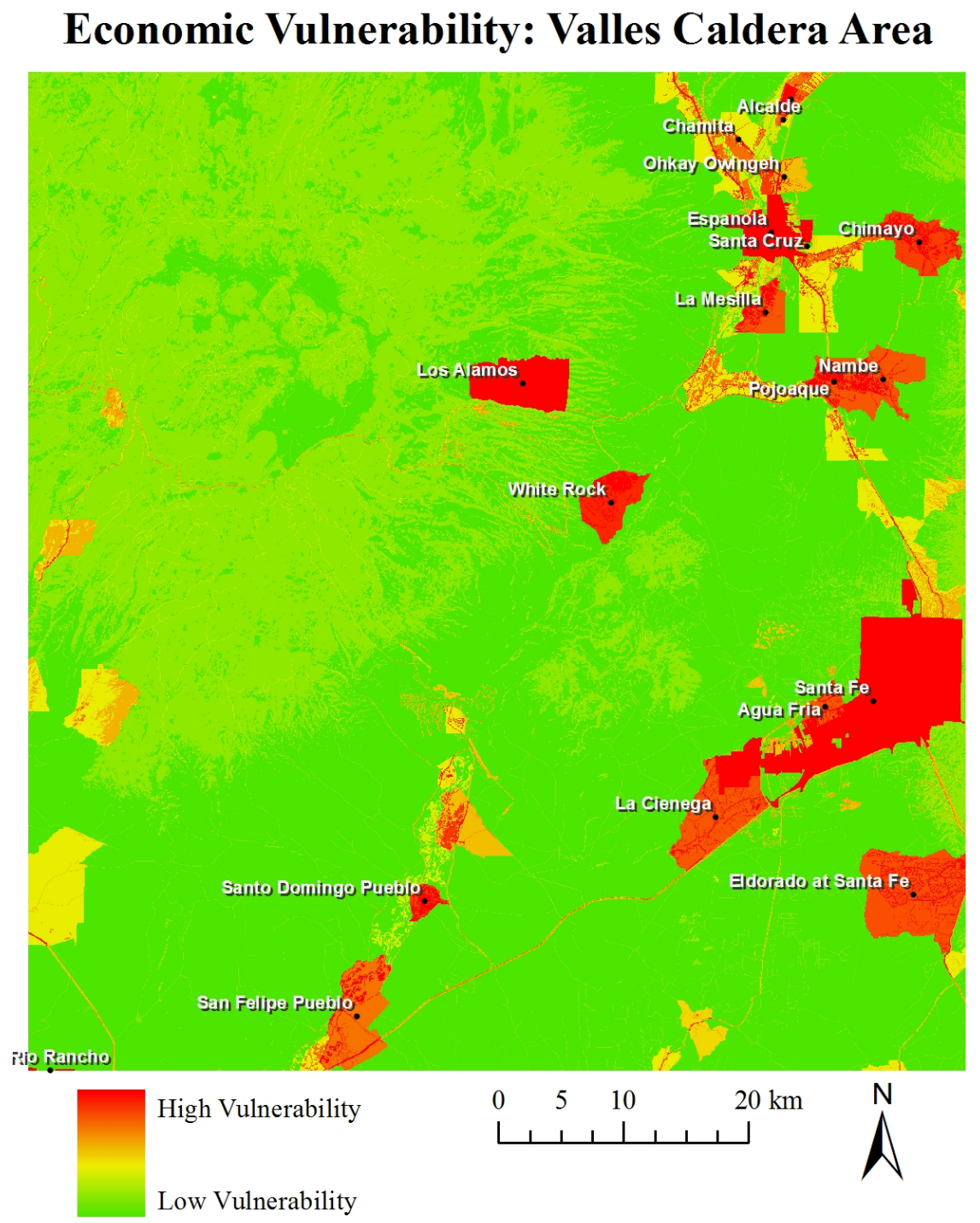

Figure 12. Map of total economic vulnerability for the entire study site. 


\section{Risk Maps for Ash Fallout Hazards}

Lower El Cajete-Type Ash at Vent A

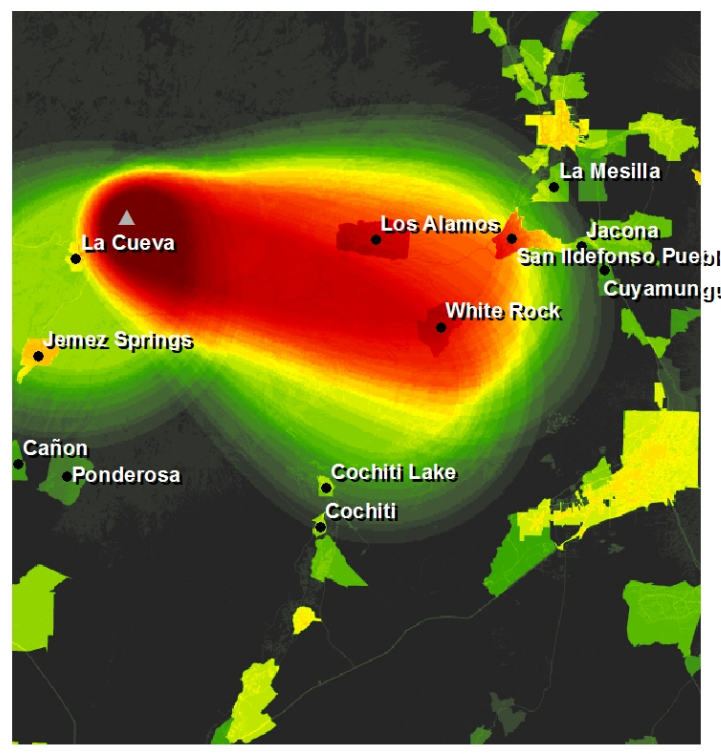

Upper El Cajete-Type Ash at Vent A

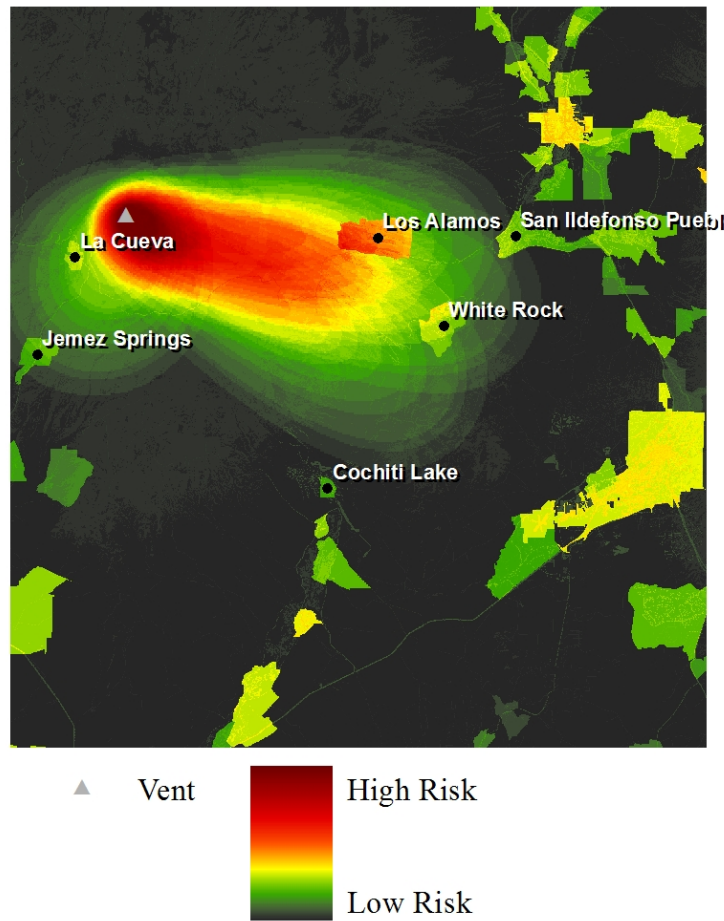

Lower El Cajete-Type Ash at Vent B

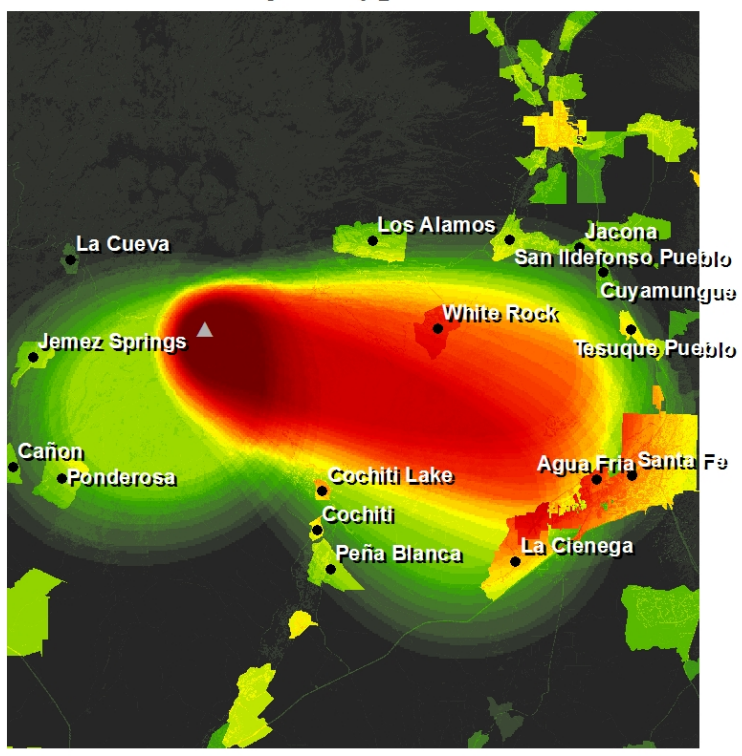

Upper El Cajete-Type Ash at Vent B

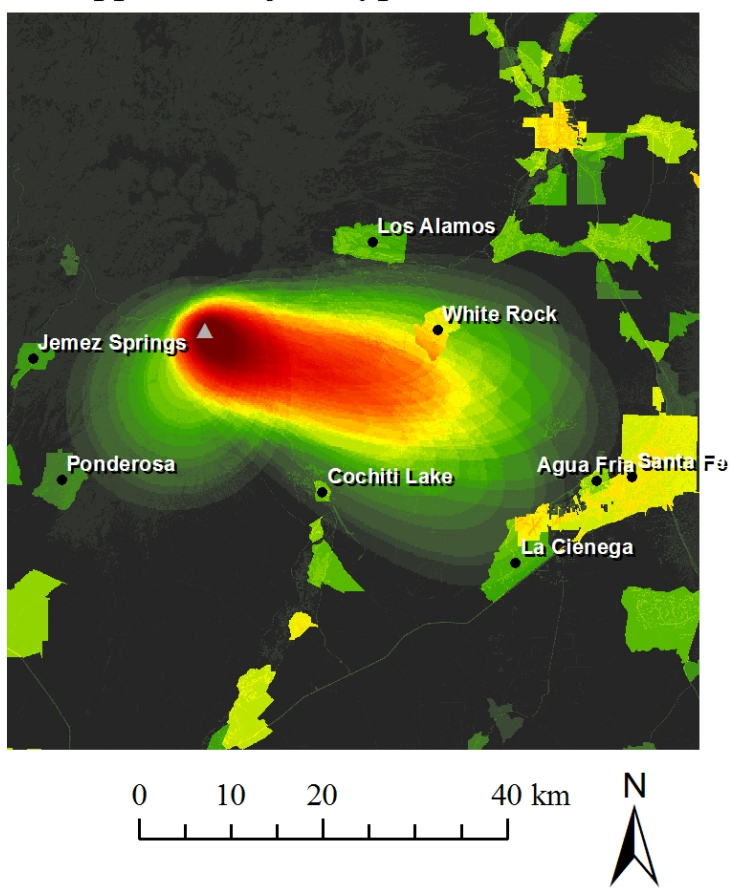

Figure 13. Total risk maps for ash fallout hazards, varied by size of eruption and location. 
Risk Map for PDC Hazards

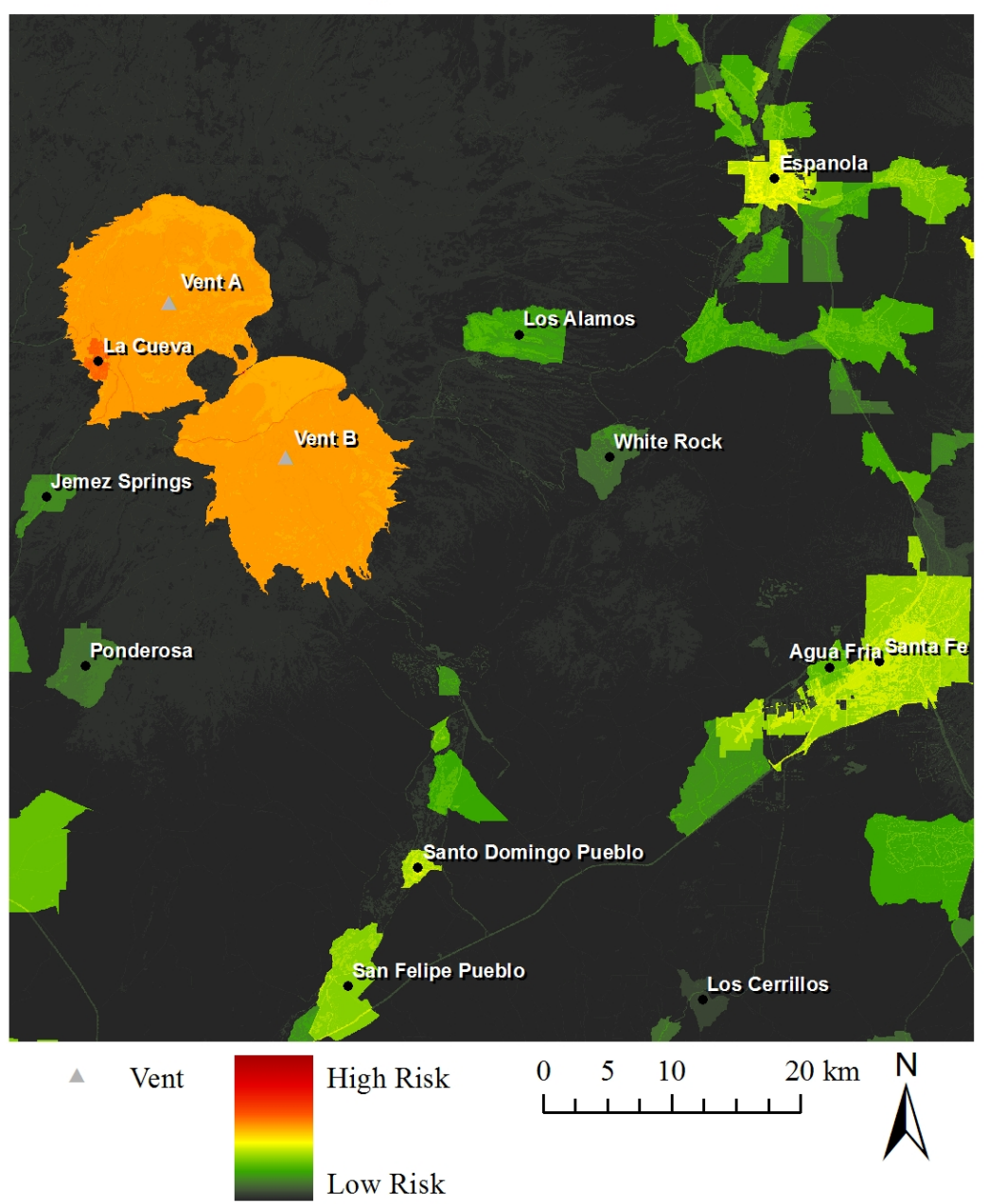

Figure 14. Total risk map for PDC hazards sourced from vents A and B. 


\section{REFERENCES}

Aceves-Quesada, J.F., Salgado, J.D., Lopex-Blanco, J., 2007. Vulnerability assessment in a volcanic risk evaluation in Central Mexico through a multi-criteria-GIS approach. Natural Hazards 40, 339-356.

Bailey, R.A., Smith, R.L., Ross, C.S., 1969. Stratigraphic nomenclature of volcanic rocks in the Jemez Mountains, New Mexico. U.S. Geological Survey Bulletin, 1247-P, 1-19.

Baldridge, S.W., Olsen, K.H., 1989. The Rio Grande Rift. American Scientist 77, 240-247.

Bell, F.G., 1999. Geologic Hazards: Their Assessment, Avoidance, and Mitigation. Spon Press, London.

Blong, R.J., 1984, Volcanic Hazards: A Sourcebook on the Effects of Eruptions. Academic Press, Sydney and Orlando.

Blong, R.J., 1996. Volcanic hazards risk assessment. In: Scarpa, R., Tilling, R.I. (Eds.), Monitoring and mitigation of volcanoes, Springer, New York, pp. 675-698.

Clarke, A.B., Voight, B., Neri, A., Macedonio, G., 2002, Transient dynamics of vulcanian explosions and column collapse. Nature 451, 897-901.

Cutter, S.L., Mitchell, J.T., Scott, M.S., 2000. Revealing the vulnerability of people and places: a case study of Georgetown County, South Carolina. Annals of the Association of American Geographers 90, 713-737.

Cutter, S.L., Boruff, B.J., Shirley, W.L., 2003, Social vulnerability to environmental hazards, Social Science Quarterly 48 (2), 242-261.

Dunbar, N.W., 2005. Quaternary volcanism in New Mexico. New Mexico Museum of Natural History and Science Bulletin 28, 95-106.

Emrich, C., Personal Communication, 2013, Hazards and Vulnerability Research Institute

Erden, T., Karaman, H., 2012. Analysis of earthquake parameters to generate hazard maps by integrating AHP and GIS for Kucukcekmece region. Natural Hazards and Earth System Sciences 12, 475-483.

Felpeto, A., Arana, V., Ortiz, R., Astiz, M., Garcia, A., 2001. Assessment and modeling of lava flow hazard on Lanzarote (Canary Islands), Natural Hazards 23, 247-257.

Felpeto, A., Marti, J., Ortiz, R., 2007. Automatic GIS-based system for volcanic hazard assessment. Journal of Volcanology and Geothermal Research 166 (2), 106-116.

Felpeto, A., 2009. VORIS a GIS-based tool for volcanic hazard assessment user's guide. 
Folch, A., Felpeto, A., 2005. A coupled model for dispersal of tephra during sustained explosive eruption. Journal of Volcanology and Geothermal Research 145, 337-349.

Gardner, J.N., Goff, F., Kelley, S., Jacobs, E., 2010. Rhyolites and associated deposits of the Valles-Toledo caldera complex. New Mexico Geology 32 (1), 3-18.

Goff, F., Rowley, J., Gardner, J.N., Hawkins, W., Goff, S., Charles, R., Wachs, D., Maassen, L., Heiken, G., 1986. Initial results from VC-1, first continental scientific drilling program core hole in Valles caldera, New Mexico. Journal of Geophysical Research 91 (B2),17421752.

Goff, F., Gardner, J.N., 2004, Late Cenozoix geochronology of volcanism and mineralization in the Jemez Mountain and Valles caldera, north central new Mexico. In: Mach, G.H., Giles, K.A. (Eds.), The Geology of New Mexico, A Geologic History. New Mexico Geological Society, 295-312.

Goff, F., 2009. Valles Caldera: A Geologic History. University of New Mexico Press, Albuquerque.

Goff, F., Gardner, J.N., Reneau, S.L., Kelley, S.A., Kempter, K.A., Lawrence, J.R., 2011. Geologic map of the Valles Caldera, Jemez Mountains, New Mexico. New Mexico Bureau of Geology and Mineral Resources 79.

Hatcher, L., 1994. A step-by-step approach to using SAS for factor analysis and structural equation modeling. SAS Institute Inc., Cary.

Hazards and Vulnerability Research Institute (HVRI), 2012. Social vulnerability index for the United States - 2006-10, http://webra.cas.sc.edu/hvri/products/sovi.aspx.

Keating, G.N., Schultz-Fellenz, E.S., Miller, E.D., 2010. Preliminary volcanic hazards evaluation for Los Alamos Nation Laboratory facilities and operations: current state of knowledge and proposed path forward. Los Alamos National Laboratory, 1-38.

Macedonio, G., Pareschi, M.T., Santacroce, R., 1988. A numerical simulation of the Plinian fall phase of 79 A.D. eruption of Vesuvius. Journal of Geophysical Research 93 (B12), 14817-18827.

Malczewski, J., 2006, GIS-based multicriteria decision analysis: a survey of the literature. International Journal of Geographical Information Science 20 (7), 703-726.

Malin, M.C., Sheridan, M.F., 1982. Computer-assisted mapping of pyroclastic surges. Science 217, 637-640. 
Marti, J., Felpeto, A., 2010. Methodology for the computation of volcanic susceptibility an example for mafic and felsic eruption on Tenerife (Canary Islands). Journal of Volcanology and Geothermal Research 195, 69-77.

Martin, A.J., Umeda, K., Conner, C.B., Weller, J.N., Zhao, D., Takahashi, M., 2004. Modeling long-term volcanic hazards through Bayesian inference: an example from the Tohoku volcanic arc, Japan. Journal of Geophysical Research 109 (B10), 1-20.

Martins, N.V., Sousa e Silva, D., Cabral, P., 2012. Social vulnerability assessment to seismic risk using multicriteria analysis: the case study of Vila Fanca do Campo (Sao Miguel Island, Azores, Portugal). Natural Hazards 62, 385-404.

Meyer, V., Scheuer, S., Haase, D., 2009. A multicriteria approach for risk mapping exemplifified at the Mulde river, Germany. Natural Hazards 48, 17-39.

Musungu, K., Motala, S., Smit, J., 2012. Using multi-criteria evaluation and GIS for flood risk analysis in informal settlements of Cape Town: the case of Graveyard Pond. South African Journal of Geomatics 1 (1), 77-91.

New Mexico Resource Geographic Information Systems Program (NMRGIS), 2011. Browse data, http://rgis.unm.edu/browsedata.

Pfieffer, T., Costa, A., Macedonio, G., 2005. A model for the numerical simulation of tephra fall deposits. Journal of Volcanology and Geothermal Research 140, 273-294.

Phillips, E.H., Goff, F., Kyle, P.R., McIntosh, W.C., Dunbar, N.W., Gardner, J.N., 2007. The ${ }^{40} \mathrm{Ar} /{ }^{39} \mathrm{Ar}$ age constraints on the duration of resurgence at the Valles caldera, New Mexico. Journal of Geophysical Research 112 (B8), 1-15.

Reneau, S.L., Gardner, J.N., Forman, S.L., 1996. New evidence for the age of the youngest eruptions in the Valles caldera, New Mexico. Geology 24, 7-10.

Schmidtlein, M.C., Deutsch, R.C., Piegorsch, W.W., Cutter, S.L., 2008. A sensitivity analysis of the social vulnerability index. Risk Analysis 28 (4), 1099-1114.

Self, S., Kircher, D.E., Wolff, J.A., 1988. The El Cajete Series, Valles Caldera, New Mexico. Journal of Geophysical Research 93 (B6), 6113-6127.

Self, S., 1990. Jemez. In: Wood, C.A., Kienle, J. (Eds.), Volcanoes of North America: United States and Canada. Cambridge University Press, New York.

Self, S., Heiken, G., Sykes, M.L., Woheltz, K., Fisher, R.V., Dethier, D.P., 1996. Field excursions to the Jemez Mountains, New Mexico. New Mexico Bureau of Mines and Mineral Resources Bulletin 134, 72. 
Sherrod, D.R., Mastin, L.G., Scott, W.E., Schilling S.P., 1997. Volcano hazards at Newberry volcano, Oregon. USGS Open-File Report 97-513.

Sparks, R.S.J., Wilson, L., Hulme, G., 1978. Theoretical modeling of the generations, movement, and emplacement of pyroclastic flows by column collapse. Journal of Geophysical Research 83 (B4), 1727-1739.

Spell, T.L., Harrison, T., 1993. ${ }^{40} \mathrm{Ar} /{ }^{39} \mathrm{Ar}$ geochronology of post-Valles caldera rhyolites, Jemez volcanic field, New Mexico. Journal of Geophysical Research 98, 8031-8051.

Spell, T.L., McDougall, I., Doulgeris, A., 1996. Cerro Toledo Rhyolite, Jemez volcanic field, New Mexico: Ar geochronology of eruptions between two-caldera forming events. Geological Soceity of America Bulletin 108, 1549-1566.

Spence, R.J.S., Kelman, I., Baxter, P.J., Zuccaro, G., Petrazzulo, S., 2005. Residential building and occupant vulnerability to tephra fall. Natural Hazards and Earth System Sciences 5, 477-494.

Steck, L.K., Thurber, C.H., Fehler, M.C., Lutter, W.J., Roberts, P.M., Baldridge, S.W., Stafford, D.G., Sessions, R., 1998. Crust and upper mantle P wave velocity structure beneath Valles caldera: results from the Jemez teleseismic tomography experiment. Journal of Geophysical Research 103 (B10), 24301-24320.

Toyos, G.P., Cole, P.D., Felpeto, A., Marti, J., 2007. A GIS-based methodology for hazard mapping of small volume pyroclastic density currrents. Natural Hazards 41, 99-112.

UNESCO, 2012. Disaster Preparedness and Risk Mitigation, United Nations Educational, Scientific and Cultural Organization, http://www.unesco.org/new/en/.

United States Geological Survey (USGS), 2010. Volcanic Ash: What It Can Do and How to Prevent Damage, http://volcanoes.usgs.gov/ash/index.html

University of Wyoming, 2013. Soundings, http://weather.uwyo.edu/upperair/sounding.html

U.S. Census Bureau, 2013. American Fact Finder, http://factfinder2.census.gov/faces/nav/jsf /pages/index.xhtml

U.S. Departmnet of Health and Human Services. 2013, Find Services Near You, healthfinder.gov /FindServices

Wang, Y., Li, Z., Tang, Z., Zeng, G., 2011. A GIS-based spatial multi-criteria approach for flood risk assessment in the Dongting Lake region, Hunan, central China. Water Resource Management 25, 3465-3484. 
Wilson, T.M., Stewart, C., Sword-Daniels, V., Leonard, G.S., Johnston, D.M., Cole, J.W., Wardman, J., Wilson, G., Barnard, S.T., 2012. Volcanic ash impacts on critical infrastructure. Physics and chemistry of the Earth 45-46, 5-23.

Wolff, J.A., Gardner, J.N., 1995. Is the Valles caldera entering a new cycle of activity?. Geology 23, 411-414.

Wolff, J.A., Brunstad, K.A., Gardner, J.N., 2011. Reconstruction of the most recent volcanic eruptions from Valles caldera, New Mexico. Journal of Volcanology and Geothermal Research 199, 53-68.

Wilcox, R.A., 1959. Some effects of volcanic ash falls with special reference to Alaska. Geological Survey Bulletin 1028-N, 409-476. 


\section{APPENDIX A: Probability Density Function Methods}

Probability density maps for each of the four geologic variables were derived through VORIS from Gaussian or Cauchy kernel functions. The Gaussian and Cauchy kernel functions indicated the probability of another event (vent, fault, fumarole, or spring) occurring at a given location as a function of the distance to other nearby events and a smoothing constant, $h$ (Martin et al., 2004). A nearest neighbor test was conducted in which the fraction of vents, faults, fumaroles or springs was plotted against the distance to the nearest neighbor. The experimental plot was then fit to theoretical plots of Gaussian or Cauchy distributions with different $h$ values to determine which kernel and smoothing factor best described each variable's spatial distribution (Figure A.1-A.4; Marti and Felpeto, 2010; Martin 2004). The R code for constructing the theoretical plots was as follows:

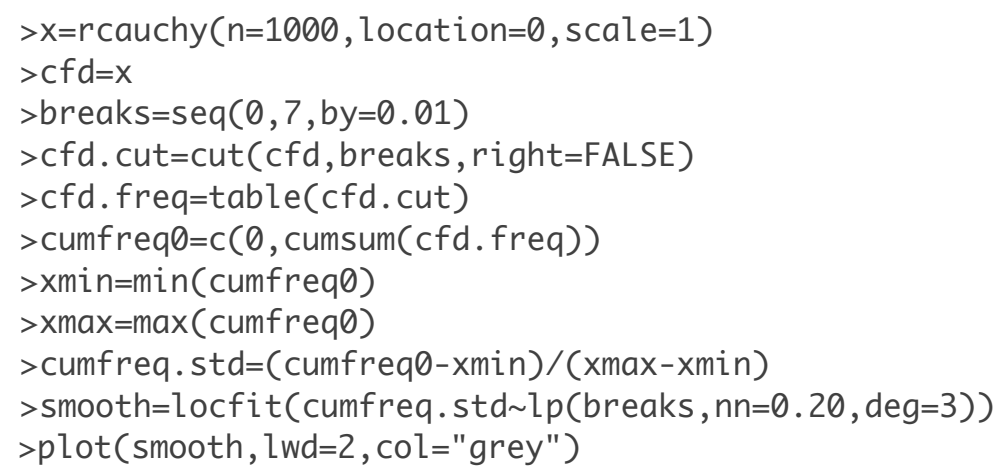

where rcauchy or rnorm was used to produce Cauchy or Gaussian curves, respectively, and the $h$ factor was varied by changes in the scale value. 

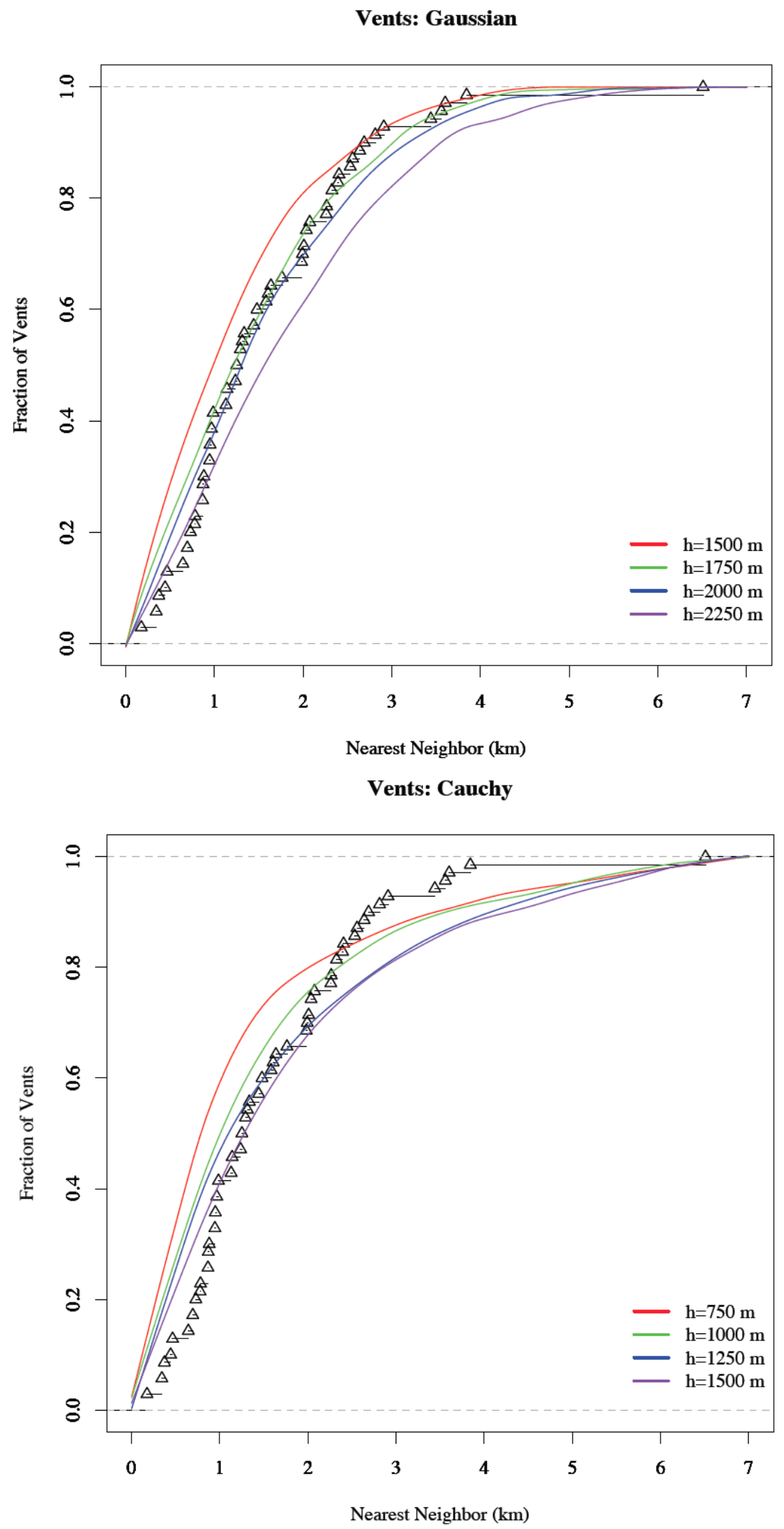

Figure A1. Nearest neighbor test for faults indicating a Gaussian kernel with a smoothing factor of $1750 \mathrm{~m}$ would best be used for calculating the probability density of vents 


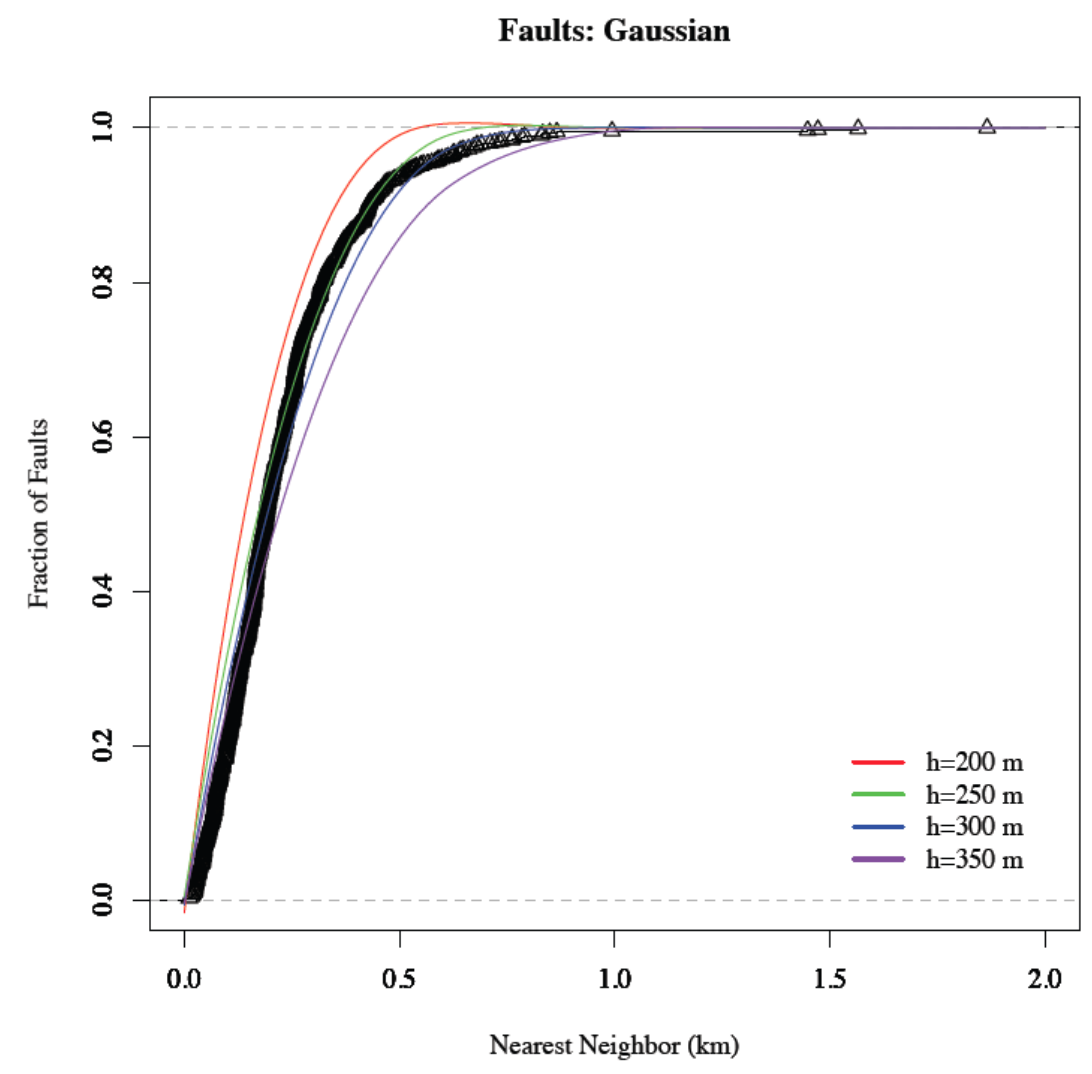

Faults: Cauchy

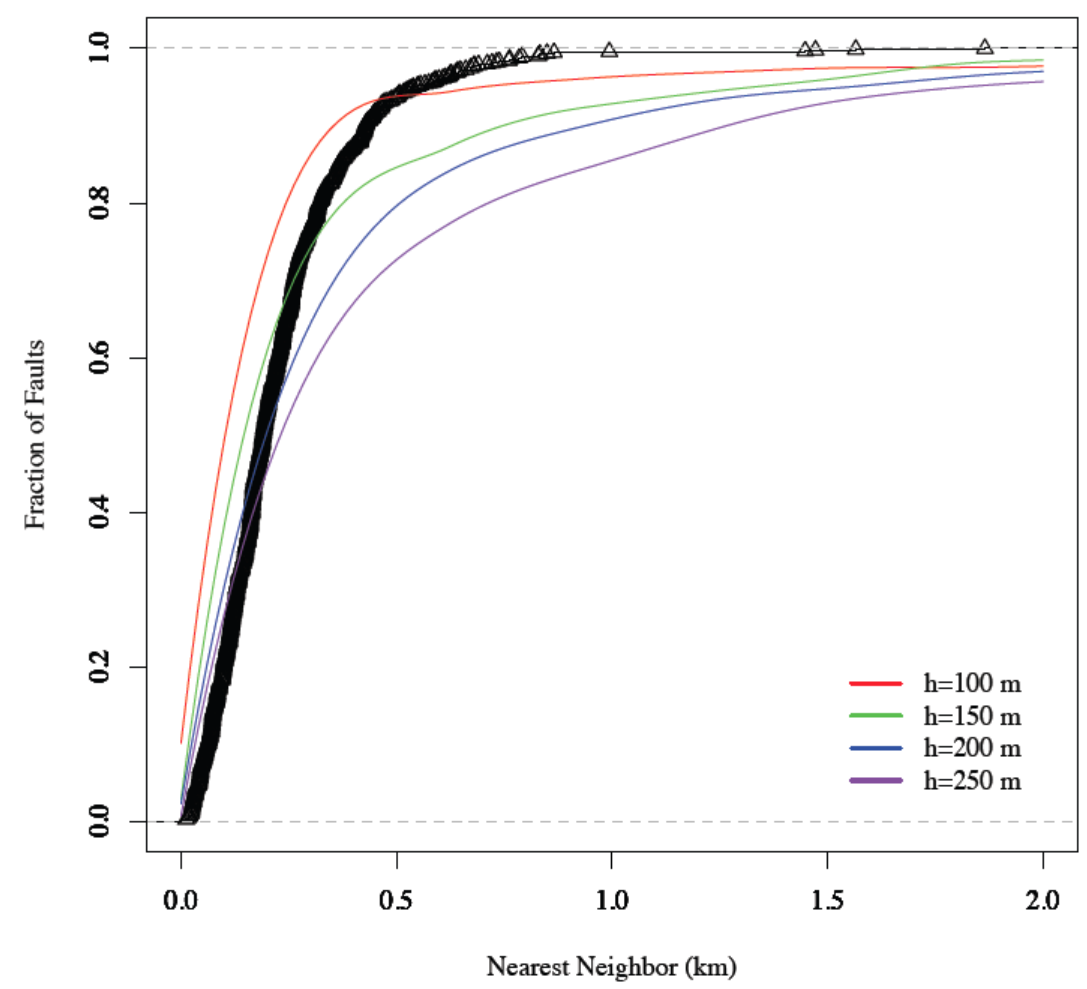

Figure A2. Nearest neighbor test for faults indicating a Gaussian kernel with a smoothing factor of $250 \mathrm{~m}$ would best be used for calculating the probability density of faults. 


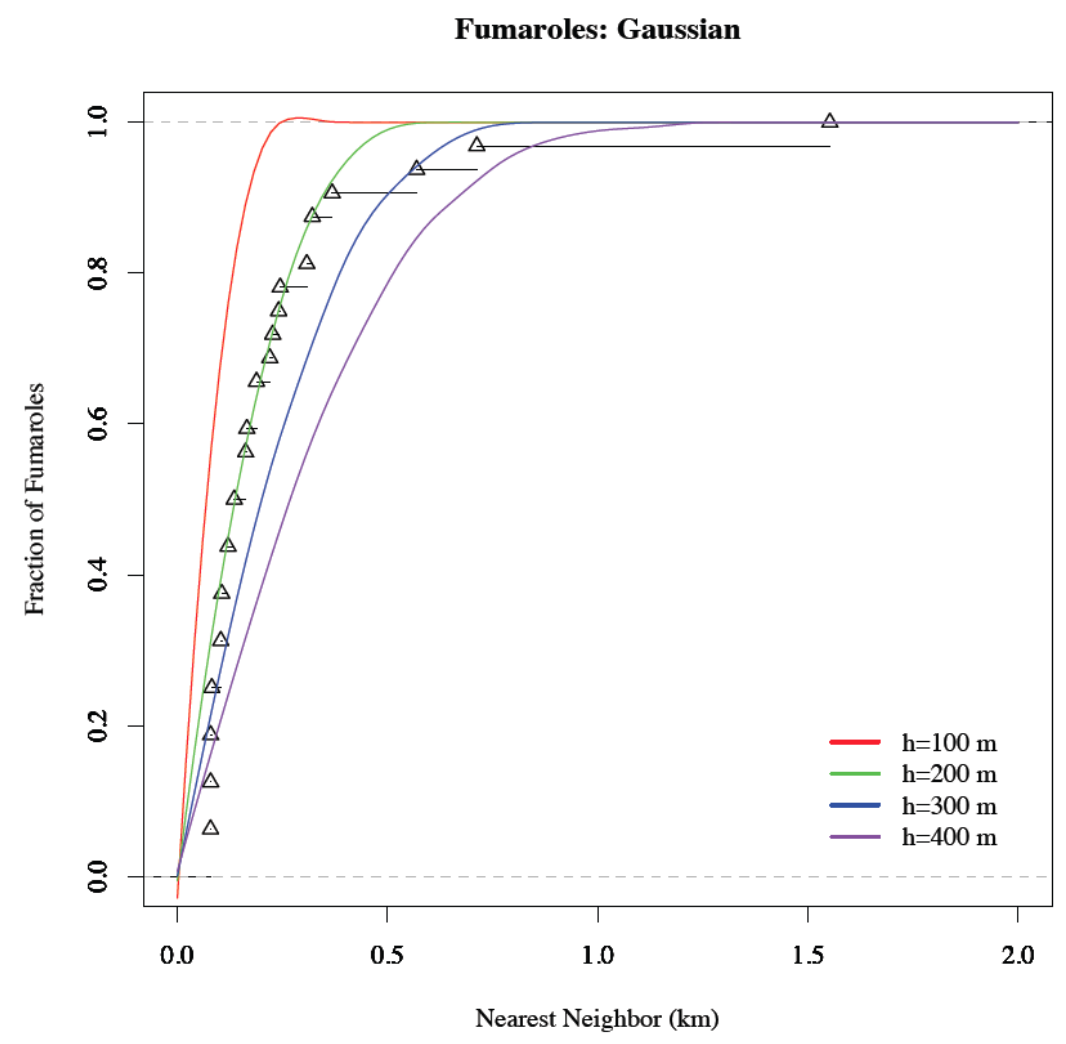

Fumaroles: Cauchy

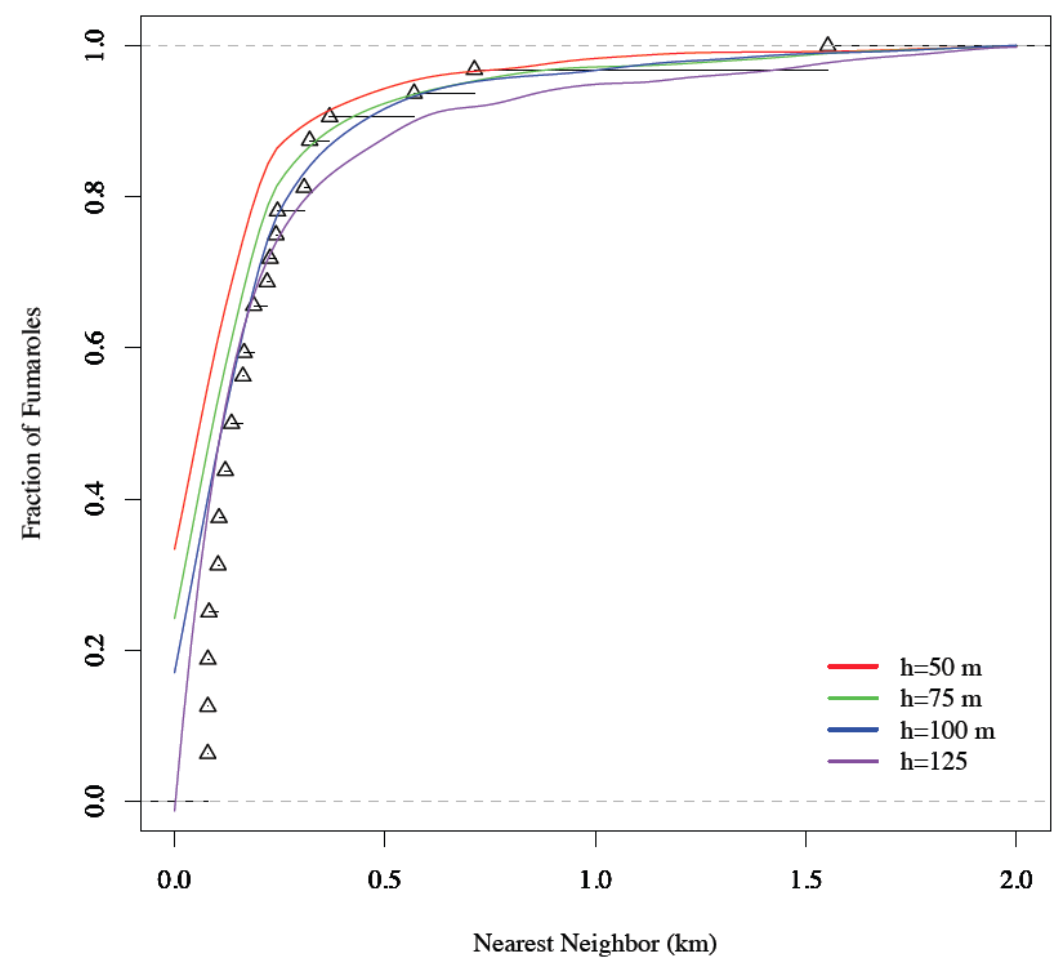

Figure A3. Nearest neighbor test for faults indicating a Gaussian kernel with a smoothing factor of $200 \mathrm{~m}$ would best be used for calculating the probability density of fumaroles. 

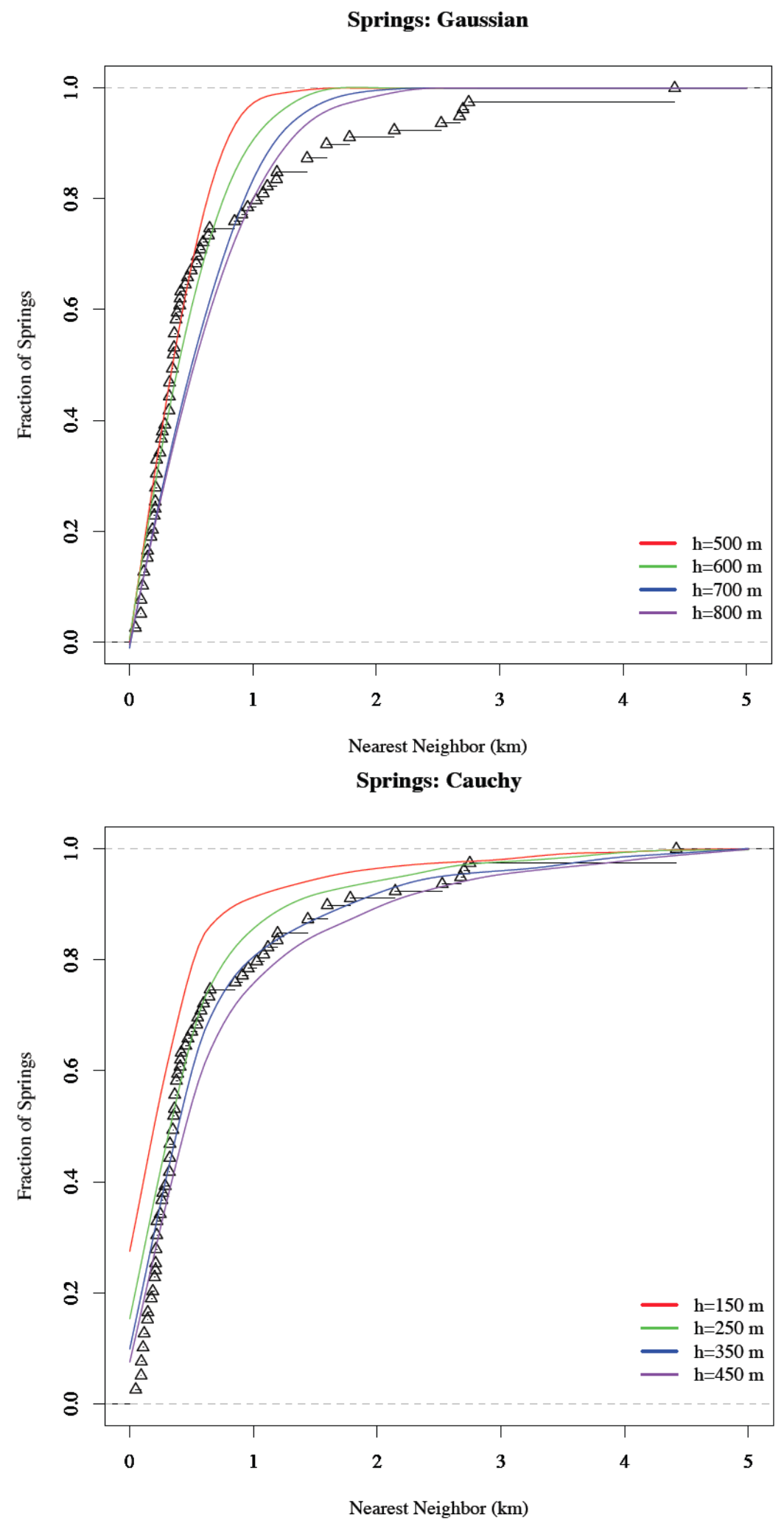

Figure A4. Nearest neighbor test for faults indicating a Cauchy kernel with a smoothing factor of $250 \mathrm{~m}$ would best be used for calculating the probability density of springs. 


\section{APPENDIX B: Ash Fallout Simulation Methods}

The following information on the ash fallout model originated from Folch and Felpeto (2005) and Felpeto (2009). The ash fallout simulation relied on an advection-diffusion model, governed by:

$$
\frac{\partial C_{j}}{\partial t}+W_{x} \frac{\partial C_{j}}{\partial x}+W_{y} \frac{\partial C_{j}}{\partial y}+W_{z} \frac{\partial C_{j}}{\partial z}-\frac{\partial v_{j} C_{j}}{\partial z}=K_{x} \frac{\partial^{2} C_{j}}{\partial x^{2}}+K_{x} \frac{\partial^{2} C_{j}}{\partial y^{2}}+K_{x} \frac{\partial^{2} C_{j}}{\partial z^{2}}+S_{j}
$$

where $C_{j}$ is the concentration of particles of class $j, t$ is time, $\left(W_{x}, W_{y}, W_{z}\right)$ are the wind field, $v_{j}$ is the fall velocity of particles of class $j, K_{x}, K_{y}$, and $K_{z}$ are the horizontal diffusion coefficients, and $S_{j}$ is the source function. For simplification, it was assumed that all of the mass is emitted at $t=0$ forming a vertical line divided into $n$ sections over the vent, vertical wind and diffusion were neglected, and horizontal diffusion coefficients were equal.

In order to determine the dispersion of particles in the eruption column, the volume of particles of a particular $\Phi$ size at any given height, $z$, was determined by the equation:

$$
V_{\phi}(z)=\left(\frac{V}{\sqrt{2 \pi} \sigma_{\phi}} e^{-\frac{\phi-\phi_{m}^{2}}{2 \sigma_{\phi}^{2}}}\right) \times \frac{\left(\left(\frac{A}{v_{\phi 0}}\right)^{2}\left(1-\frac{Z}{H_{T}}\right)\left(e^{\frac{A}{v_{\phi 0}}\left(\frac{z}{H_{T}}-1\right)}\right)\right)}{H_{c}\left(1-\left(1+\frac{A}{v_{\phi 0}}\right) e^{-\frac{A}{v_{\phi 0}}}\right)}
$$

where $\mathrm{V}$ is the total volume, $\Phi_{m}$ is the mean value of the particle distribution $\sigma_{\Phi}$ is the standard deviation of the particle distribution, $H_{T}$ is the maximum height of the eruption column, $\mathrm{A}$ is a column shape factor, and $v_{\Phi 0}$ is the terminal settling velocity of particles of size $\Phi$ at sea level.

For every class of particles considered $\left(\Phi_{1}, \Phi_{2}, \Phi_{3}, \ldots, \Phi_{N}\right)$ and for every vertical section, VORIS calculated the trajectory of the center of the mass of particles based on the terminal fall velocity, horizontal diffusion, and the advection from wind until the mass reached the ground surface. 
Once the deposition location of the center of the mass for a given particle size and column section was determined, the time that it took for the mass to cross each layer was summed for a total fall time. The total fall time was then be used to determine the thickness of particles of size $\Phi$ that fall from height $z_{i}$ by the equation:

$$
\begin{aligned}
T_{\phi j}=\frac{V_{\phi j}}{4 \Delta x^{2}}( & \left.\operatorname{erf}\left(\frac{\Delta x-\left(\mathrm{x}-x_{0 \phi j}\right)}{2 \sqrt{K t_{\text {fall } \phi j}}}\right)+\operatorname{erf}\left(\frac{\Delta x+\left(\mathrm{x}-x_{0 \phi j}\right)}{2 \sqrt{K t_{\text {fall } \phi j}}}\right)\right) \\
& -\left(\operatorname{erf}\left(\frac{\Delta x-\left(\mathrm{y}-y_{0 \phi j}\right)}{2 \sqrt{K t_{\text {fall } \phi j}}}\right)+\operatorname{erf}\left(\frac{\Delta x+\left(\mathrm{y}-y_{0 \phi j}\right)}{2 \sqrt{K t_{\text {fall } \phi j}}}\right)\right)
\end{aligned}
$$

where $\left(x_{0 \Phi_{j}}, y_{O \Phi_{j}}\right)$ is the location of the center of the mass at ground level and $\Delta x$ is the size of the source function. The total thickness of the deposit was calculated by summing the deposit thickness from every column section for each class of particles. 


\section{APPENDIX C: PDC Simulation Methods}

The simulations for PDCs relied on the use of an energy cone model for determining which cells in a DEM may be impacted by the hazard. In this model, an energy line, with a starting point at the collapse equivalent height of the source and an inclination of $\theta$, was extended $360^{\circ}$ around the source to define the energy cone (Malin and Sheridan, 1982; Toyos et al., 2007; Felpeto, 2009). The intersection of the energy line with the ground determined the distal limits of the PDC. The model then calculated if cell $i j$ would be affected by the PDC if $h_{i j}$ $>0$, where:

$$
h_{i j}=H_{0}+H_{c}-d_{i j} \tan \theta-h_{0 i j}
$$

and $H_{0}$ is the topographic height of the vent, $H_{c}$ is the collapse equivalent height, $d_{i j}$ is the distance from the vent to cell $i j, \theta$ is equal to $\arctan \left(H_{c} / L\right)$, and $h_{o i j}$ is the topographic height of cell $i j$. Since the energy cone model only considers individual cells and not the influence of the surrounding topography, an accessibility algorithm was then used to prevent the PDC from accessing cells that are actually protected by topographic barriers (Toyos et al., 2007; Felpeto, 2009). The final result is a binary map, where cells that are impacted by the PDC are assigned a value of 1 and all other cells a value of 0 (Toyos et al., 2007; Felpeto, 2009). 


\section{APPENDIX D: Lava Flow Simulation Methods}

The following description of the lava flow model was derived from Felpeto et al. (2001) and Felpeto (2009). The model for lava flow simulations was predominantly topography driven. The primary assumption was that the flow in any given cell could only move to its neighboring cells if the elevation in the occupied cell was greater than the elevation of the neighboring cell. The probability of the flow propagating to any one of its eight neighboring cells $(i=1,2, \ldots, 8)$ was given by:

$$
P_{i}=\frac{\Delta h_{i}}{\sum_{j=1}^{8} \Delta h_{j}}
$$

where,

$$
\begin{gathered}
\Delta h_{i}=h_{0}+h_{c}-h_{i} \text { if }\left(h_{0}+h_{c}-h_{i}\right) \geq 0 \\
\Delta h_{i}=0 \text { if }\left(h_{0}+h_{c}-h_{i}\right)<0
\end{gathered}
$$

and $h_{0}$ is the elevation of the cell occupied by the flow, $h_{c}$ is a user-specified height correction accounting for the thickness of the lava flow, and $h_{i}$ is the height of the cell under evaluation. The selection of which cell the flow will actual enter was determined through a Monte Carlo algorithm. Additionally, the model accounted for possible topographic sinks, where the occupied cell has a lower elevation than the eight neighboring cells even with the height correction. In this situation, the model considered that in nature the sink would fill and the flow would most likely continue on; therefore, in the case of a sink the model looked to the neighboring sixteen cells. If any of the sixteen cells was accessible for the flow to continue, the model proceeded, otherwise the flow stopped. In order to prevent the simulated flow from reaching an inexplicable length, a user-defined maximum flow length is also incorporated into the model to stop the flow at a realistic point. Multiple iterations were run during a single simulation to account for many 
possible paths; the probability of each cell being occupied by the lava flow was determined by the ratio of the number of paths that have crossed that cell to the total number of paths. 


\section{APPENDIX E: Principal Component Analysis}

In order to optimize the twenty-four variables used in the analysis of the social vulnerability index, the standardized variables for $228 \mathrm{CDPs}$ were put into a principal component analysis with the use of SPSS, a software specialized for statistical analysis. The output provided loading scores indicating how each variable correlated with each component, as well as the eigenvalues, from which the variance for each component was calculated and proportion of the variance explained by each component (Table E1). Using this information, the components were reduced to the most statistically optimal for farther analysis based on the Kaiser criterion, which states that all components with an eigenvalue greater than one should be used for analysis (Hatcher, 1994; Emrich personal communication, 2013). Following the Kaiser criterion, if all components with an eigenvalue greater than one were extracted, the analysis would be reduced to the first eight components. The first eight components were then rotated through varimax rotation to maximize the variance (Table E1).

Following the rotation of the components, the factor loadings for each component were then used to determine which variables correlated highly with each component (Table E2). Additionally, as directed by HVRI (2012) methods, appropriate cardinalities for each of the components were assigned depending on the variable loadings to assure positive component loadings were associated with increased vulnerability and negative component loadings were associated with decreased vulnerability. Ethnicity, age, class, poverty/unemployment, and gender were assigned positive cardinality, while wealth, wealth/extractive employment, and race were assigned negative cardinality. The two components representing wealth were assigned negative cardinality due to the fact that wealth allows communities to recover from disaster more readily due to insurance, social safety nets, and entitlement programs (Cutter et al., 2003). Additionally, 
race was assigned negative cardinality due to the fact that the variable loaded negatively on the component, however African American minorities are considered to increase social vulnerability. Based on the cardinality, the component scores for each CDP were summed together for a total social vulnerability score with the following equation:

$$
\text { SoVI }=\text { Ethnicity }+ \text { Age }+ \text { Class }+ \text { Poverty }- \text { Wealth }- \text { Extractive }+ \text { Gender }- \text { Race }
$$


Table E1. The variance explained for the initial principal component analysis of all twenty-four variables and the eight optimal components before and after rotation.

\begin{tabular}{|c|c|c|c|c|c|c|c|c|c|}
\hline \multirow{2}{*}{ Component } & \multicolumn{3}{|c|}{ Initial Eigenvalues } & \multicolumn{3}{|c|}{$\begin{array}{c}\text { Extraction Sums of Squared } \\
\text { Loadings }\end{array}$} & \multicolumn{3}{|c|}{$\begin{array}{c}\text { Rotation Sums of Squared } \\
\text { Loadings }\end{array}$} \\
\hline & Total & $\begin{array}{c}\text { \% of } \\
\text { Variance }\end{array}$ & $\begin{array}{c}\text { Cumulative } \\
\%\end{array}$ & Total & $\begin{array}{c}\text { \% of } \\
\text { Variance }\end{array}$ & $\begin{array}{c}\text { Cumulative } \\
\%\end{array}$ & Total & $\begin{array}{c}\text { \% of } \\
\text { Variance }\end{array}$ & $\begin{array}{c}\text { Cumulative } \\
\%\end{array}$ \\
\hline 1 & 4.307 & 17.944 & 17.944 & 4.307 & 17.944 & 17.944 & 2.999 & 12.494 & 12.494 \\
\hline 2 & 2.788 & 11.618 & 29.562 & 2.788 & 11.618 & 29.562 & 2.562 & 10.676 & 23.170 \\
\hline 3 & 2.031 & 8.463 & 38.025 & 2.031 & 8.463 & 38.025 & 2.290 & 9.541 & 32.711 \\
\hline 4 & 1.652 & 6.883 & 44.908 & 1.652 & 6.883 & 44.908 & 1.910 & 7.960 & 40.671 \\
\hline 5 & 1.310 & 5.460 & 50.367 & 1.310 & 5.460 & 50.367 & 1.641 & 6.837 & 47.508 \\
\hline 6 & 1.187 & 4.946 & 55.314 & 1.187 & 4.946 & 55.314 & 1.619 & 6.747 & 54.254 \\
\hline 7 & 1.120 & 4.668 & 59.982 & 1.120 & 4.668 & 59.982 & 1.317 & 5.489 & 59.744 \\
\hline 8 & 1.073 & 4.470 & 64.451 & 1.073 & 4.470 & 64.451 & 1.130 & 4.707 & 64.451 \\
\hline 9 & .978 & 4.076 & 68.527 & & & & & & \\
\hline 10 & .910 & 3.793 & 72.320 & & & & & & \\
\hline 11 & .853 & 3.556 & 75.876 & & & & & & \\
\hline 12 & .822 & 3.423 & 79.299 & & & & & & \\
\hline 13 & .703 & 2.931 & 82.230 & & & & & & \\
\hline 14 & .667 & 2.780 & 85.010 & & & & & & \\
\hline 15 & .561 & 2.336 & 87.346 & & & & & & \\
\hline 16 & .491 & 2.047 & 89.394 & & & & & & \\
\hline 17 & .480 & 2.002 & 91.396 & & & & & & \\
\hline 18 & .436 & 1.816 & 93.211 & & & & & & \\
\hline 19 & .430 & 1.790 & 95.001 & & & & & & \\
\hline 20 & .331 & 1.380 & 96.382 & & & & & & \\
\hline 21 & .274 & 1.143 & 97.525 & & & & & & \\
\hline 22 & .252 & 1.050 & 98.575 & & & & & & \\
\hline 23 & .180 & .751 & 99.327 & & & & & & \\
\hline 24 & .162 & .673 & 100.000 & & & & & & \\
\hline
\end{tabular}


Table E2. Variable loadings on each of the eight optimal components, highlighting the optimal components for each component.

\begin{tabular}{|c|c|c|c|c|c|c|c|c|}
\hline & \multicolumn{8}{|c|}{ Component } \\
\hline & $\begin{array}{c}1 \\
\text { Ethnicity } \\
\text { (Native } \\
\text { American) }\end{array}$ & $\begin{array}{c}2 \\
\text { Age }\end{array}$ & $\begin{array}{c}3 \\
\text { Class }\end{array}$ & $\begin{array}{c}4 \\
\text { Poverty and } \\
\text { Unemployment }\end{array}$ & $\begin{array}{c}5 \\
\text { Wealth }\end{array}$ & $\begin{array}{c}6 \\
\text { Wealth } \\
\text { and } \\
\text { Extractive }\end{array}$ & $\begin{array}{c}7 \\
\text { Gender }\end{array}$ & $\begin{array}{c}8 \\
\text { Race } \\
\text { (Black) }\end{array}$ \\
\hline & $(+)$ & $(+)$ & $(+)$ & $(+)$ & $(-)$ & $(-)$ & $(+)$ & $(+)$ \\
\hline QFEMALE & .050 & .135 & -.004 & .045 & .012 & -.022 & .853 & -.082 \\
\hline QAGEDEP & -.154 & .741 & -.033 & .036 & -.097 & .032 & .429 & .049 \\
\hline MEDAGE & -.583 & .393 & -.198 & -.299 & .188 & -.112 & -.125 & .034 \\
\hline QBLACK & -.034 & .005 & -.051 & .018 & .027 & -.040 & .075 & -.880 \\
\hline QASIAN & .040 & -.028 & .071 & .092 & .721 & .069 & -.126 & -.097 \\
\hline QHISP & -.681 & .008 & .279 & .072 & -.299 & .166 & .060 & .155 \\
\hline QNATAM & .845 & .126 & .054 & .181 & -.050 & -.118 & -.126 & .005 \\
\hline QMOHO & -.135 & -.275 & .632 & -.241 & -.200 & .290 & -.016 & .009 \\
\hline QRENTER & .098 & -.266 & -.159 & .691 & -.066 & -.001 & -.052 & .217 \\
\hline QNOAUTO & .151 & .592 & .231 & .076 & .123 & -.161 & -.130 & .157 \\
\hline MDHSEVAL & -.317 & -.062 & -.492 & -.111 & .474 & -.024 & .195 & .103 \\
\hline MDRENT & -.225 & -.088 & -.123 & -.368 & .558 & .003 & .197 & .083 \\
\hline QFEMLBR & -.064 & -.712 & -.019 & -.051 & .046 & -.141 & .049 & .347 \\
\hline QCVLUN & .201 & .083 & .025 & .538 & -.011 & -.054 & .011 & -.058 \\
\hline QSERV & .145 & .041 & .678 & .119 & .082 & -.182 & .256 & .020 \\
\hline QEXTRCT & -.032 & .077 & -.062 & -.084 & -.143 & .791 & -.018 & .003 \\
\hline QRICH & -.012 & .073 & -.079 & -.033 & .282 & .821 & .008 & .036 \\
\hline QSSBEN & -.126 & .796 & -.019 & -.139 & -.147 & .201 & .163 & .049 \\
\hline PERCAP & -.351 & -.067 & -.469 & -.390 & .470 & .005 & .021 & .093 \\
\hline QPOVTY & .013 & .071 & .343 & .668 & -.041 & -.090 & .138 & -.109 \\
\hline QFHH & .647 & .039 & .069 & .130 & -.090 & .067 & .021 & .230 \\
\hline PPUNIT & .789 & -.125 & .143 & .056 & -.141 & .014 & .132 & -.056 \\
\hline QED12LES & .054 & .359 & .639 & .076 & -.034 & -.181 & -.172 & .133 \\
\hline QESL & -.032 & .006 & .428 & .352 & .075 & -.076 & -.298 & .009 \\
\hline
\end{tabular}




\section{APPENDIX F: Data for Economic Vulnerability}

Data on the population, housing units, and economic production were gathered from the U.S. Census Bureau 2007-2011 American Community Survey for each CDP or economic unit. To determine the number of schools per CDP, the address for each school in Rio Arriba, Sandoval, Santa Fe, and Los Alamos counties was extracted from the New Mexico Educational Personnel Directory 2011-2012, which listed all public, private, charter, state-supported, regional education cooperative, high education, kindergarten, and special education schools in the state. The addresses were then geocoded with the North American Address Locator in ArcGIS. The schools were then clipped to leave only schools within the study site, and summarized based on city to determine the number of schools per CDP. A similar approach was used for the hospitals, however the addresses for the medical facilities, including community health centers, hospitals, and nursing homes were derived from the U.S. Department of Health and Human Services instead. Land use data was derived from the 2006 National Land Cover Database and road types were downloaded from the 2010 Census Bureau road shapefiles for New Mexico. 